\title{
Rise of Indian Outward FDI: What Implications Does it Hold for Host Developing Countries?
}

\author{
Jaya Prakash Pradhan*
}

\begin{abstract}
This study has analyzed the overall and regional trends in Indian direct investment flows into developing region since 1960s and explored various development impacts they have on host developing countries. Evidence tends to indicate that developing region was the initial destination for Indian outward investing firms and continued to receive their attention over time. Developing region bound Indian FDI, which was led by a small group of Indian firms in a few selected developing countries in 1960-80, is now giving way to a more extensive pattern with large quantum of outward investment. A large number of Indian firms are undertaking increasing investment activities across different sub-regional developing groups and for a variety of firm-specific motivations.
\end{abstract}

Number of clasification: JEL: F23; O18, R10

Keywords: Indian FDI; Indian multinationals, India; developing countries.

\section{RESUMEN}

Este estudio analiza las tendencias regionales y totales de los flujos de inversión extranjera directa india en regiones en desarrollo desde los años sesenta, y explora algunos de los impactos de estos flujos en los países huéspedes. La evidencia tiende a indicar que las regiones en desarrollo fueron el destino inicial de las inversiones extranjeras indias y continuaron siéndolo a lo largo del tiempo. La inversión extranjera directa que emprendió un pequeño grupo de empresas indias en regiones en desarrollo se realizó en pocos países en desarrollo seleccionados entre 1960 y 1980, y está actualmente conduciéndose hacia un patrón extensivo, con un amplio nivel de inversiones hacia afuera. Un gran número de empresas indias han emprendido crecientes inversiones a partir de diferentes grupos de subregiones en desarrollo y con diversas motivaciones especificas de las empresas.

Número de clasificación: JEL: F23; O18, R10

Palabra clave: IED trasnacionales de la India y países en desarrollo.

* Profesor Asociado, Instituto de Investigación Económica y Social Sarder Patel, Gujarat, India [pradhanjayaprakash@gmail.com]. La presente es una versión resumida de un estudio realizado para el programa IED para países en desarrollo i TIC UNCTAD's Programme on South-South FDI and Developing Country TNCs and released as the ISID Working Paper, No. 2008/08. El autor agradece a los dictaminadores anónimos sus valiosas sugerencias para una versión anterior de este artículo of the journal for their useful suggestions on the earlier draft of the paper. 


\section{INTRODUCTION}

A broad-based political and economic consensus - South-South Cooperationemerged among many southern/developing countries during the period 1970-1980. These developing countries wanted to benefit from reciprocal sharing of development experience with each other in the fields of finance, technology, skills, industry, services and trade. This cooperation also underlined the efforts of the South (i.e. developing countries) to minimize its excessive dependence on the North (i.e. developed countries) for financial and technological supports. In this context, south-south investment has been seen as a very useful instrument for fostering development in the developing region by ensuring provision of finance, relevant technologies, skills and marketing practices. However, in spite of the contemporary political and policy focus on south-south investment during that period, the subject of intra-regional foreign direct investment (FDI) by developing country enterprises remained an inadequately researched area of knowledge, particularly with respect to the estimation of magnitude of such FDI flows and evaluating their specific role in the development of southern region.

With the rise of outward FDI from developing countries since 1990s, there has been a renewed research interest in the phenomenon of south-south investment. An emergent literature (Aykut and Rath, 2004; Bhattat and Aykut, 2005; Aykut and Goldstein, 2007; Goldstein, 2007) has come to recognize the growing incidents of developing country firms undertaking FDI activities in fellow developing countries. This has led to a much faster growth rate of south-south FDI flows as compared to the rate at which FDI has flown from developed countries to developing countries in the 1990s. Aykut and Rath (2004) estimated that the share of south-south FDI in total FDI inflows into developing region increased from about 6 per cent in 1994 to reach 36.4 per cent in 2000. Although available estimates on intra-developing region FDI flows is patchy due to the problem of under-reporting of outward FDI (OFDI) data by many home developing countries, and existence of the phenomenon of round-tripping and offshore financial centres, recent studies do indicate that a larger part of this recent growth of developing region OFDI is driven by intra-regional activities.

This paper is motivated to contribute to the current literature on southsouth FDI from an analysis of India as a FDI source for other developing countries. The Indian experience can give valuable insight into the dynamics of south-south FDI for a number of reasons. First, Indian multinationals are pioneers among developing country enterprises that lead to the emergence of the south-south 
investment flows and played a lead role in sustaining that flow over time. The successful establishments of a textile factory by the Birla group at Addis Ababa, Ethiopia, in 1960 and an assembly plant for sewing machines by the Shriram group at Ratmalana, Sri Lanka, in 1962 were perhaps two known cases of earliest south-south investment projects. Since then Indian multinationals along with firms from a few other developing countries until the 1980s and from a large number of developing countries since 1990s are providing further impetus to the growth process of south-south investment flows. ${ }^{1}$ Second, India has explicitly incorporated the philosophy of South-South Cooperation in her OFDI policy regime during 1960-1980 and had encouraged specific type of OFDI projects (e.g., joint ventures as opposed to wholly-owned subsidiaries and required imparting of training to host country partners by Indian investors), which are thought to be more development generating in fellow developing countries. Third, India has been making considerable technological progress in many knowledge-based sectors like pharmaceuticals, automobiles, information technologies, etc., and it would be interesting to examine the hypothesis of intermediate technologies that developing country OFDI is often ascribed to possess.

This study addresses the following specific questions regarding Indian FDI in developing countries: What are the trends in Indian investment in developing region? Where do Indian companies operate and in which sectors of host developing economies? Which ownership strategies do these firms pursue and why? What are the forms of Indian investment in developing countries? Is the hypothesis of intermediate technologies still valid for Indian investment? What are the drivers of Indian FDI flows into developing countries? How are host developing countries affected by Indian investment? While discussing the host country impacts of Indian FDI, the study chooses an exploratory analysis that focuses on quality dimension of FDI projects. The quantity of direct investments by Indian firms is certainly an important source of capital formation in host developing countries but their overall development impact is crucially dependent on the specific type and forms of economic activities that are being undertaken and the extent of their inter-linkages with local productive processes.

The next section I examines the trends and patterns of Indian investments in developing regions since 1960s. Section II discusses the main drivers of

\footnotetext{
${ }^{1}$ A few of developing countries such as India, Argentina, Brazil, South Korea, Singapore, Indonesia, Thailand, Malaysia, Hong Kong, Taiwan, South Africa were active in developing country outward fdi during 1970-1980 and they were joined by an increasing number of emerging countries such as Chile, China, Egypt, Mexico, Malaysia, Russia, Turkey, etc., since 1990s.
} 
Indian FDI. Section III explores the role of Indian FDI in the development of host developing countries. Finally, in last section summarizes the study.

\section{TREndS AND PATTERnS OF INDIAN FDI IN DEVELOPING REgION}

\section{Trends in Indian OFDI}

The internationalization process of Indian enterprises through OFDI has in fact begun with their involvement in developing countries of the world economy. Direct investment projects of India's early multinationals went mostly into the developing region that emerged as the leading host region to Indian OFDI, accounting for 68.6 per cent of OFDI flows during 1961-1969 (Table 1). The share of developing region further increased in 1970s to attain its highest shares ever: 96 per cent. The attraction of developing region to Indian OFDI continued to be very high in the 1980s. While developed region started enhancing its position since 1990 s and has overtaken developing region in 2000-2007 as the most attractive host region, developing countries continued to be important locations for outward investing Indian companies. Over 1961-2007, a total of 1674 Indian parent companies invested more than US $\$ 10.9$ billion in as many as 92 developing countries. This widespread cross-country distribution of Indian OFDI in the developing region further confirmed the prominent roles that Indian multinationals are playing in other developing countries.

The fact that developing countries were the leading recipients of Indian OFDI during 1960-1980 largely reflects the intermediate nature of ownership advantages possessed by Indian companies during that period (Pradhan, 2008 a, $2008 \mathrm{~b}$ ). The main technological advantage that these Indian firms achieved through absorbing, assimilating, adapting and reverse engineering of foreign technologies offered limited scope for exploitation in developed region. The modified foreign technologies to suit local demand and factor conditions rather provided Indian innovating firms certain competitive advantages in other developing countries having similar socio-economic conditions like India. Besides the proximity of space, culture and ethnicity, the cordial policy attitude that existed among developing countries for FDI projects originating in fellow developing countries all have attracted early Indian multinationals into developing countries.

The process developing innovative activities of many Indian firms and from a wide range of industrial activities moved towards product development in the 1990s. For example, in the case of Indian pharmaceutical sector a number 
TABLE 1. Regional Trends of Indian OFDI Flows, 1961-2007

\begin{tabular}{|c|c|c|c|c|c|c|c|c|c|}
\hline \multirow{2}{*}{ Period } & \multicolumn{3}{|c|}{ OFDI value (US\$ million) } & \multicolumn{3}{c|}{ No. of outward investing firms } & \multicolumn{3}{|c|}{ No. of host countries } \\
\cline { 2 - 10 } & Developing & Developed & Total & Developing & Developed & Total & Developing & Developed & Total \\
\hline $1961-1969$ & $\begin{array}{c}22 \\
(68.6)\end{array}$ & $\begin{array}{c}10 \\
(31.4)\end{array}$ & $\begin{array}{c}32 \\
(100)\end{array}$ & 6 & 6 & 11 & 6 & 2 & 8 \\
\hline $1970-1979$ & $\begin{array}{c}84 \\
(96.2)\end{array}$ & $\begin{array}{c}3 \\
(3.8)\end{array}$ & $\begin{array}{c}87 \\
(100)\end{array}$ & 52 & 9 & 60 & 15 & 2 & 17 \\
\hline $1980-1989$ & $\begin{array}{c}116 \\
(76.3)\end{array}$ & $\begin{array}{c}36 \\
(23.7)\end{array}$ & $\begin{array}{c}152 \\
(100)\end{array}$ & 106 & 55 & 146 & 29 & 9 & 38 \\
\hline $1990-1999$ & $\begin{array}{c}1890 \\
(56.4)\end{array}$ & $\begin{array}{c}1460 \\
(43.6)\end{array}$ & $\begin{array}{c}33351 \\
(100)\end{array}$ & 692 & 687 & 1257 & 61 & 27 & 88 \\
\hline $2000-2007 *$ & $\begin{array}{c}8788 \\
(36.0)\end{array}$ & $\begin{array}{c}15652 \\
(64.0)\end{array}$ & $\begin{array}{c}24440 \\
(100)\end{array}$ & 1012 & 1327 & 2104 & 78 & 28 & 106 \\
\hline All years & $\begin{array}{c}10900 \\
(38.8)\end{array}$ & $\begin{array}{c}17162 \\
(61.2)\end{array}$ & $\begin{array}{c}28061 \\
(100)\end{array}$ & 1674 & 1866 & 3149 & 92 & 30 & 122 \\
\hline
\end{tabular}

*Data for 2001 is only from January to March, 2002 is from October to December and 2007 data is from January to March. Percentage share in parenthesis. Developing region includes developing countries and transition economies of South-East Europe as classified by the UNCTAD in World Investment Report 2006.

Source: Calculation based on a dataset compiled from unpublished remittance-wise information from Reserve Bank of India, published reports of Indian investment centre and unpublished firm-level information from Ministry of Commerce.

of Indian companies started out-licensing their molecules to global multinationals based in developed countries (Pradhan, 2008b). This maturing technological strength of large-sized Indian firms is now allowing them to exploit their competitive advantages even in developed countries and hence 1990s onwards developed region began to emerge as an attractive destination for Indian OFDI. Consequently, the share of developed region in Indian OFDI has grown steadily from 23.7 per cent in 1980s to 44 per cent in 1990 and further to 64 per cent in 2000-2007. The rising role of developed countries is also due to the adoption of overseas acquisitions by a large number of Indian firms to access foreign technologies and knowledge mostly concentrated in innovation driven developed region (Pradhan and Abraham, 2005; Pradhan, 2008 a). Another factor that explains the improved attractiveness of developed countries to Indian OFDI is the rise of service firms like software, communication, etc., as global players mostly focused on service-dominated developed countries (Pradhan, 2003). 
Notwithstanding this growing attractiveness of developed countries as a host to Indian OFDI since 1990s, Indian investment in developing region has also been growing rapidly. Between 1990-1999 and 2000-2007, Indian firms' investment in developing countries increased by more than five-times from US \$1.9 billion to reach US $\$ 8.8$ billion. This trend suggests that Indian firm's OFDI expansion into developed countries is not at the cost of developing countries.

\section{Regional Geography}

The OFDI flows from India have evolved differently over time in different subregional groupings within the developing region. During 1960s, a number of Indian companies got interested in tapping business opportunities thrown open since the starting of industrialization programme in many African countries that had recently achieved their independence. Indian firms also got attracted to Africa because of the historical business link established since British colonial era and presence of significant size of Indian origin population. Africa emerged as the largest host of developing region Indian OFDI flows in 1961-1969 with 60 per cent share and hosting three Indian multinationals (Table 2). The other region that attracted Indian OFDI is the Asia and Oceania that hosted about four Indian overseas investors and accounted for 40 per cent of the total Indian FDI flows into the developing region. The geographical proximity of Asian countries, cultural linkages and similarity of institutions inherited from colonial rule appear to be important locational factors of neighbouring Asian countries (IIFT, 1977). Developing countries in Latin America and the Caribbean and SouthEast Europe and CIS, largely due to geographical distance, language barriers, and weak trade links, failed to attract any Indian investment during this period (Agrawal, 1984).

During 1970-1980, Indian OFDI flows into Africa declined mainly because of growing policy restrictions on foreign investment, political violence and internal strife. The absolute amount of Indian investment received by Africa has gone down from \$35 million in 1970 to reach $\$ 25$ million in 1980. Although the number of Indian companies hosted by Africa has increased from 11 to 24 between 1970 and 1980, its share in southern Indian investment decreased from 42 per cent to 21.9 per cent in 1980-1989. The relative attractiveness of Asian countries to Indian OFDI has gone up since 1970. Factors such as stable political conditions, healthy market trends and foreign investment friendly regimes of many Asian countries pulled an increasing number of outward investing Indian firms. During 
TABLE 2. Regional Distribution of Indian FDI flows into Developing Region, 1961-2007

\begin{tabular}{|c|c|c|c|c|c|}
\hline \multirow[b]{2}{*}{ Period } & \multicolumn{5}{|c|}{ FDI flows in $\$$ million } \\
\hline & Africa & $\begin{array}{l}\text { Latin America } \\
\text { and Caribbean }\end{array}$ & $\begin{array}{l}\text { Asia and } \\
\text { Oceania }\end{array}$ & $\begin{array}{c}\text { Southeast } \\
\text { Europe and CIS }\end{array}$ & $\begin{array}{c}\text { Total developing } \\
\text { region }\end{array}$ \\
\hline 1961-1969 & $\begin{array}{c}13 \\
(60.0)\end{array}$ & & $\begin{array}{c}9 \\
(40.0)\end{array}$ & & $\begin{array}{c}22 \\
(100)\end{array}$ \\
\hline 1970-1979 & $\begin{array}{c}35 \\
(42.0)\end{array}$ & & $\begin{array}{c}46 \\
(55.1)\end{array}$ & $\begin{array}{c}2 \\
(2.9)\end{array}$ & $\begin{array}{c}84 \\
(100)\end{array}$ \\
\hline 1980-1989 & $\begin{array}{c}25 \\
(21.9)\end{array}$ & $\begin{array}{c}0.2 \\
(0.2)\end{array}$ & $\begin{array}{c}61 \\
(52.5)\end{array}$ & $\begin{array}{c}29 \\
(25.4)\end{array}$ & $\begin{array}{c}116 \\
(100)\end{array}$ \\
\hline 1990-1999 & $\begin{array}{c}317 \\
(16.8)\end{array}$ & $\begin{array}{c}47 \\
(2.5)\end{array}$ & $\begin{array}{l}1445 \\
(76.4)\end{array}$ & $\begin{array}{c}81 \\
(4.3)\end{array}$ & $\begin{array}{l}1890 \\
(100)\end{array}$ \\
\hline $2000-2007$ & $\begin{array}{l}2968 \\
(33.8)\end{array}$ & $\begin{array}{r}1132 \\
(12.9)\end{array}$ & $\begin{array}{l}3407 \\
(38.8)\end{array}$ & $\begin{array}{l}1281 \\
(14.6)\end{array}$ & $\begin{array}{l}8788 \\
(100)\end{array}$ \\
\hline All years & $\begin{array}{l}3358 \\
(30.8)\end{array}$ & $\begin{array}{r}1179 \\
(10.8)\end{array}$ & $\begin{array}{l}4968 \\
(45.6)\end{array}$ & $\begin{array}{r}1394 \\
(12.8)\end{array}$ & $\begin{array}{l}10900 \\
(100)\end{array}$ \\
\hline \multicolumn{6}{|c|}{ Number of outward investing firms } \\
\hline 1961-1969 & 3 & & 4 & 1 & 6 \\
\hline 1970-1979 & 11 & & 43 & 1 & 52 \\
\hline 1980-1989 & 24 & 2 & 86 & 3 & 106 \\
\hline 1990-1999 & 152 & 19 & 493 & 83 & 692 \\
\hline $2000-2007$ & 245 & 43 & 794 & 32 & 1012 \\
\hline All Years & 398 & 61 & 1298 & 112 & 1674 \\
\hline \multicolumn{6}{|c|}{ Number of host countries } \\
\hline $1961-2007$ & 28 & 15 & 35 & 14 & 92 \\
\hline
\end{tabular}

Note \& Source: Same as table 1 .

1980-1989 more than half of the developing region Indian OFDI has been directed at Asian region with the participation of as many as 86 Indian companies. Latin America and the Caribbean and South-East Europe and CIS developing countries witnessed initial interest of Indian entrepreneurs.

With the liberalization of policy regime including OFDI of the home country in the 1990s, Indian multinationals intensified their investment activities in developing regions across different sub-regional groups. Almost all developing sub-regions experienced rapid growth in Indian investment led by a growing number of Indian parent companies. Between 1980 and 1990, the number of Indian investing companies increased from 24 to 152,86 to 493,2 to 19 and 3 
to 83 respectively in Africa, Asia and Oceania, Latin America and the Caribbean and South-East Europe and CIS. Similar to the past trends, Asia and Oceania followed by Africa were the two most attractive sub-developing regions in this period as well.

The geographical pattern of Indian OFDI in developing countries has shown trends of spatial diversification during 2000-2007. The developing region picture of Indian OFDI which used to be dominated by a single host developing region, either by African developing countries in 1961-1969 or by Asian developing countries in 1970-1999, is now well spread across developing regions. In 2000-2007, the host Asia \& Oceania region received about 39 per cent of Indian OFDI flows, followed by Africa with 34 per cent, South-East Europe and CIS with 15 per cent and Latin America and Caribbean with 13 per cent.

\section{a) Africa}

Indian OFDI flows into Africa grew rapidly during the period 2000-2007 as compared to the past. FDI flows in 2000-2007 were 836 per cent higher than in 19901999 (Appendix Table A1). This substantial growth in Indian investment in Africa was accompanied by a marked geographical spread. Although Indian companies' entry into Africa was limited to Nigeria, Kenya and Uganda in the 1970s, the number of African countries hosting Indian FDI has gone up significantly to 28 by $2000-2007$.

Among African sub-regions, East Africa largely led by Mauritius emerged as the largest host region accounting for about 73 per cent of the total Indian OFDI flows into Africa during 1961-2007. Mauritius alone attracted about 70 per cent of Indian OFDI flows into Africa. Routing overseas investment through Mauritius directed at other host countries and even bringing back the investment into the home country is very attractive for Indian companies as they can avail benefits of low rates of dividend and income taxes in Mauritius and as well benefits from double tax avoidance treaties that other countries have signed with Mauritius. Being an offshore financial centre, it also attracted large number of Indian software companies catering to the financial service providers. Kenya is another important East African host country for Indian investment since 1970. Indian OFDI in Kenya has been into a wide range of sectors from low technology industries to knowledge-based industries. The maximum cases of Indian OFDI were in pharmaceuticals followed by machinery and equipment, chemicals, textiles and wearing apparel and paper and paper products. The long standing cultural, trade and eth- 
nic links that Kenya has with India are the important locational factors attracting Indian investment into it.

North Africa is the second most attractive sub-region in Africa for Indian OFDI. Sudan, among North African countries, has emerged as the top destination and in fact is the second important African host to Indian investment after Mauritius. About 12 per cent of the total Indian FDI in African region was located in Sudan. Although India shares a strong bond of common heritage and culture with Sudan since ancient times, the phenomena of Indian investment in Sudan is of recent origin - beginning since 2003. It is also largely confined to the natural resource seeking investment made by a public sector Indian company, ONGC Videsh Limited (OVL), in the oil and gas sector. OVL has acquired 25 per cent stake in Greater Nile Oil Project in March 2003, 26.1 per cent and 24.5 per cent stake respectively in exploration blocks 5A and 5B in November 2007. Apart from Indian OFDI in Sudanese oil sector, small quantum of Indian investment can be noticed in the case of automobile components and light engineering goods. Clearly the main motivation of Indian investment in Sudan is, until now, accessing her large oil reserves. Like Sudan, Indian investment in Libya - the second most important North African host country - is of recent origin. In spite of the formation of Indo-Libyan Joint Commission way back in 1978 to promote co-operation between the two countries in economic and industrial fields, Indian companies' participation in Libya remained confined to project execution in the areas of construction, transmission and other development activities. Libya's friendly relationship with India, adoption of a flexible visa regime, and possession of the biggest oil reserve in Africa is likely to see more investment by Indian companies aspiring to control oil resources abroad.

West Africa is the third attractive region in Africa for Indian investment after East and North African regions with about 8 per cent share of the total Indian OFDI received by Africa during 1961-2007. The low share of West Africa in Indian OFDI is not surprising given the prolonged history of wars and conflicts in prominent West African countries like Liberia, Nigeria and Senegal.

Other African sub-regions like Central Africa and Southern Africa have attracted minimal proportion of Indian direct investment destined to Africa during 1961-2007. Their shares are 1.9 per cent and 1.4 per cent respectively.

Sectoral Trends. Indian investments in Africa are fairly well diversified sectorally to cover a wide range of economic activities. Initially, Indian OFDI in Africa during 1960-1980 has been largely into the manufacturing sector but its rapid 
surge since 1990 s is increasingly led by primary and service sectors. In terms of the cumulative Indian OFDI flows into Africa during 1961-2007, manufacturing is still the largest single sector attracting about $\$ 1877$ million, nearly 56 per cent of the total Indian investment (Appendix Table A2). A total of 229 Indian manufacturing companies have undertaken direct investment across 15 individual industries and directed at a total of 23 African host countries. Within the manufacturing sector, the main industrial areas are chemicals (32 per cent), rubber and plastics (8 per cent), transport equipment (3.7 per cent), basic metal and products ( 2.2 per cent), and machinery and equipment (1.7 per cent). This broad industrial pattern of Indian manufacturing investment in Africa tends to go with the postulations of several recent studies on Indian OFDI that Indian outward investing firms are no longer confined to the traditional labour-intensive and low technology based industries (Pradhan, 2008a, 2008b). By the 1990s, Indian firms from a number of knowledge-based sectors like chemicals, pharmaceuticals, transport equipments, etc., have achieved significant technological strengths through in-house R\&D efforts and acquisition of foreign technologies via several modes like licensing, merger and acquisitions (M\&As), reverse engineering, etc. This growing technological sophistication of Indian firms from technology-intensive industries is now increasingly driving their outward FDI activities in general and similar is the case within Africa.

Africa's service sector accounts for about 26 per cent of the total Indian investments during 1961-2007 to emerge as the second important host sector after manufacturing. Within services, the largest share of Indian investment occurs in software and ITEs (9.6 per cent), followed by financial and insurance services (7.5 per cent), transportation services ( 5 per cent), and film and entertainment (1.8 per cent). There are about 163 Indian parent service companies investing in 17 African countries across different sub-regions. In the case of software and ITES, Mauritius is the largest host African country. The well developed landline and mobile telephonic infrastructure, high information and communication technology (ICT) penetration, and bilingual manpower of Mauritius have attracted more investments by Indian information and technology (IT) companies. South Africa with its large skilled multi-lingual workforce, low wage, and proximity to the Middle East and Europe has emerged as the second attractive location for Indian IT investment. Kenya and Uganda are other African countries that have attracted Indian software companies.

Indian investment in Africa's financial services covers a range of activities such as stock broking and mutual fund, investment management and advi- 
sory services, asset and portfolio management, leasing, insurance and setting up of investment holding companies. Mauritius being a financial centre is the largest host country for Indian financial services investment in Africa. For Indian companies establishing offshore investment holding companies in Mauritius provides significant tax advantage as mentioned earlier. Apart from Mauritius, African countries that have attracted Indian investment in financial sector include Egypt, Ethiopia, Kenya, Nigeria, South Africa, Zambia, and Zimbabwe. Almost all Indian investments in Africa's transportation services are directed at a single African country, Mauritius. These include activities like aviation, shipping and courier businesses.

\section{b) Latin America and the Caribbean}

As compared to other developing sub-regions, Indian firms' entry into Latin America and the Caribbean is of recent origin and involves relatively small amount of direct investment. The period over 1980-1990, the cumulative value of Indian investment in Latin America and the Caribbean stands at just US \$47 million (Appendix Table A3). However, a rapid expansion in Indian investment has been registered of late during 2000-2007. The value of Indian OFDI stock in Latin America stood at US \$1 179 million at end March 2007 and involved a total of 61 Indian parent companies.

The sub-region of the Caribbean and Other America led by Bermuda has been the top Latin American host to Indian investment. About 45 per cent of the total Indian FDI in Latin America (US \$531 million) is destined to Bermuda. Except one Indian OFDI project in the telecommunication services led by Reliance Infocomm Limited, all other Indian OFDI projects in Bermuda - an offshore financial centre - are in the software and information technology (IT) sector. A total of eigth Indian software companies have invested in Bermuda to serve the demand for software services emanating from a cluster of international financial services companies operating in the areas of insurance, investment funds and special purpose vehicles. ${ }^{2}$ Cuba, Trinidad and Tobago, St Vincent, and the Bahamas are other destinations in the Caribbean and Other America that have attracted a small amount of Indian investment involving a few Indian companies.

South America is the second important sub-regional host to Indian OFDI

\footnotetext{
${ }^{2}$ Investing Indian companies are HCL Infosystem Limited, HCL Perot Systems, HCL Technologies Limited, HT Interactive Media properties Limited, Slocum Investment Pvt. Limited, SSI Limited, Trigyn Technologies Limited and Wipro Limited.
} 
directed at Latin America. It has attracted a cumulative Indian investment of US $\$ 533$ million in 1980-2007, nearly 45 per cent of the total Indian investment hosted by Latin America. However, Indian OFDI in South America is mostly concentrated in a single country, namely Brazil. Apart from being India's largest trading partner in Latin America, Brazil possesses substantial hydrocarbon reserves and a large and growing market in the Latin American region to be attractive for Indian multinationals from natural resource segment, pharmaceuticals and other sectors. The added advantage of locating subsidiaries in Brazil is that Indian companies get easy access to the common market of Mercosur representing other countries such as Argentina, Paraguay and Venezuela (as members) and Chile and Bolivia (as associating countries). With Mercosur entering into a Preferential Trade Agreement (PTA) with India in March 2005, this new mechanism is likely to offer a great variety of investment opportunities to Indian companies.

Central American countries are the least attractive hosts for Indian OFDI with just about 8 per cent share of the total Indian investment in Latin America. Mexico with US \$68 million and Panama with US \$26 million are the important Central American host countries. Indian investment in Mexico that began in 1993 has really picked up during 2000-2007. Most aggressive Indian investors in Mexico are from the pharmaceutical sector who have invested about US \$53 million (78.6 per cent of the total). The main locational factors that are attracting Indian investment into Mexico are access to the largest market of the world represented by trading block of the North American Free Trade Agreement (NAFTA) consisting of Mexico, Canada and the US, and low wage cost advantage. The Indian FDI into Mexico is expected to grow faster in the backdrop of India and Mexico signing a ten-year bilateral investment promotion and protection agreement in May 2007. ${ }^{3}$ Indian investment in Panama dates back to 1988 and covers a range of industrial operations. Tea, shipping, and medical transcription services have been the main sectors of Indian investment although small amount of Indian FDI can be seen in software services, textiles and construction and engineering services.

Sectoral Trends. Nearly all economic sectors of Latin America have witnessed significant growth in Indian FDI inflows between 1990 and early 2000. Sectoral breakups suggest that more than half of the Indian OFDI stock in Latin America is in services sector, followed by primary sector (36 per cent) and manufacturing sector (14 per cent) (Appendix Table A4). A total of 26 Indian service companies

\footnotetext{
${ }^{3}$ Hindu (2007), 'India, Mexico sign investment protection agreement', May 22.
} 
are operating in 10 Latin American host countries. Software and telecommunication services are the two most important services sector respectively accounting for 30 per cent and 18 per cent of the total Indian investments in Latin America. Within the primary sector, it is the oil and gas segment that is the important host for Indian investment. Oil and gas-seeking Indian investment is wholly undertaken by one state-owned company, OVL Limited, and was directed at two Latin American countries, namely Brazil and Cuba. The pattern of manufacturing investment in Latin America is broad-based but mostly dominated by pharmaceuticals and food and beverages segments.

\section{c) Asia and Oceania}

Indian multinationals have a long history of activity in Asian region since 1961. As mentioned earlier, the pull forces of geographical and cultural proximity have been the traditional determining factors of Indian investment in this sub-region. The amount of Indian FDI into Asia has consistently grown from a meagre US \$9 million in 1960 to US $\$ 61$ million in 1980 and quite substantially since 1990 to reach US \$3.4 billion in 2000-2007 (Appendix Table A5). As many as 1298 Indian parent companies have invested in this region. Clearly, Indian firms are relatively more active intra-regionally in terms of number of outward investing firms and the amount invested. This intra-regional character of Indian OFDI can be partly explained by the neighbourhood effects involving similarity in culture, business environment, and institutions and partly by the superior growth that the Asia and Oceania region has exhibited (due to economies like China, Singapore, Hong Kong, South Korea, and Taiwan) as compared to other developing regions.

South-East Asia has been the largest sub-regional host to Indian investing companies accounting for about 48 per cent of the total Indian FDI in Asia and Oceania region. Singapore with 35 per cent turns out to be the single largest South-East Asian host country and also the top attractive destination for Indian FDI into Asia and Oceania. With its highly developed financial, telecommunication and other trade-supporting infrastructure, Singapore has been the most favourite place for Indian companies due to its liberal foreign investment policies and its advantage in offering preferential access to the ten-member ASEAN (Association of South East Asian Nations) market and a host of 13 other countries including Japan, USA, and Australia with whom Singapore has free trade agreements. Indonesia, Thailand and Malaysia are other attractive destinations for Indian investment in South-East Asian region. 
West Asia with US $\$ 1.2$ billion of Indian investment is the second largest host in the Asian region after South-East Asia. A total of 413 Indian parent companies have been operating in this sub-region with UAE as the principal destination. The starting of free zones scheme at Jebel Ali and Sharjah with approvals for full foreign ownership and tax-free regime seems to be a major factor attracting Indian companies into UAE. ${ }^{4}$ The past cultural and business links, cordial political relations, existence of a strong Indian expatriate community and well-developed ports and airport facilities all are positively motivating Indian investment into UAE. Oman hosted a total of 31 Indian parent companies and accounted for 5 per cent of the total Indian FDI in Asia to emerge as the next attractive West Asian country after UAE. With the investment protection and avoidance of double taxation agreement that Oman has with India and proactive encouragement to Indian companies for investment, Oman is likely to see more improvement in investment flows from India.

East Asia is the third largest host to Indian FDI in Asia and Oceania region. A total of 181 Indian parent companies have invested an aggregate of US \$1.02 billion in East Asia. Hong Kong (a Special Administrative Region of China) with 15 per cent and China with 4 per cent of the total Indian FDI in Asia are two important host countries. Indian companies appear to be leveraging familiar laws, institutions and culture of Hong Kong to access the mainland Chinese and global markets.

South Asia is the fourth important Asian sub-region to host Indian FDI. It has attracted about US $\$ 341$ million undertaken by a total of 297 Indian parent companies. Predominantly Indian investment in South Asia has been concentrated in two countries, namely Sri Lanka and Nepal. Beside the pull factors like geographical and cultural proximities, the recent spurt in Indian investment into Sri Lanka is caused by the operation of India-Sri Lanka Free Trade Agreement in 2000. In addition to the geographical, cultural and historical ties with India, Nepal has a double tax avoidance treaty and a very liberal policy approach to Indian companies. In fact for many Indian small- and medium-sized enterprises that are first-time trans-nationalizers, Nepal is a natural choice with lower risks.

Indian investment in the Oceania has been quite limited and just amounts to US \$3 million. Only two Indian parent companies, namely Forbes Gokak Limited and Asian Paints (India) Limited are operating in this developing sub-region of Asia.

\footnotetext{
${ }^{4}$ Hindu Business Line (2000), 'Indian companies warm up to UAE free zones', July 25.
} 
Sectoral Trends. Indian firms that started investing intra-regionally during 19611969 all were from the manufacturing sector. In 1970s, Indian services firms also joined the OFDI process in investing in the Asian region. However, the rate of OFDI investment undertaken by service firms outpaced that undertaken by manufacturing firms in early 2000s. Between 1990-1999 and 2000-2007, OFDI investment by Indian service firms grew by 312 per cent as compared to 96 per cent of manufacturing firms and 68 per cent of firms from primary sector (Appendix Table A6).

For the overall period from 1961-2007, the sectoral distribution of Indian investment in Asia shows that nearly 57.5 per cent of it went to the manufacturing sector, 32 per cent to the service sector and the remaining 10 per cent to the primary sector. The growth of Indian manufacturing OFDI in Asia is accompanied by a growth of 749 investing Indian companies from as many as 16 individual industries and directed at a total of 33 Asian host countries. Of these individual industries, chemicals received the largest amount of manufacturing investment (US \$547 million) and has greater geographical spread of 23 host countries. Transport equipment, computer and electronics, basic metals and fabricated metal products, pharmaceuticals, electrical machinery and equipment, food and beverages and gems and jewellery are other important sectors.

A total of 520 Indian service firms invested about US \$1586 million in as many as 24 Asian host countries. The activities of Indian software firms in Asia represent the largest category with US $\$ 451$ million accounting for about 9 per cent of the total Indian FDI in the sub-region. Telecommunication services, film and entertainment, construction and engineering services are other important host sectors for Indian services FDI projects.

The primary sector Indian investment in Asia is largely into the oil and gas sector. Of the US $\$ 492$ million of Indian FDI in the petroleum sector, US \$122 million went to UAE ( 25 per cent), US \$103 million went to Iran (21 per cent), US $\$ 75$ million went to Vietnam (15 per cent), and US \$63 million went to Myanmar (13 per cent). Although public owned oil and gas companies such as ONGC Videsh Limited, Indian Oil Corporation Limited, Hindustan Petroleum Corporation Limited and Gail (India) Limited are leading outward investing companies, recently a number of privately owned Indian companies such as Gulf Oil Corporation, Shivvani Oil and Gas Exploration, Shakun Gases, Great Eastern Shipping Co, Aban Offshore and Haresh Petrochem Limited are also undertaking such natural asset-seeking investments. 


\section{d) South-East Europe and CIS}

The expansion of outward investing Indian firms into South-East Europe and CIS sub-region started in 1979. Usha Martin Limited - an Indian company - established a joint venture company in Bosnia and Herzegovina (formerly a part of Yugoslavia) for manufacturing steel rope with an investment of US \$2.4 million for 17.5 per cent of equity interest. In the 1980 s, there are just about three cases of OFDI by Indian companies in this developing sub-region. The trend in Indian OFDI picked up during 1990-1998 significantly and reached a brief lull during 1999-2001 before accelerating from 2002 onward with a large number of OFDI projects. At end March 2007, a total of 112 Indian parent companies are operating in 14 South-East Europe and CIS countries with an aggregate investment of US \$1394 million (Appendix Table A7).

The CIS sub-region largely led by Russia came out as the most attractive destination for Indian FDI in South-East Europe and CIS region with as high as 99 per cent share. Russia alone accounted for 81 per cent of Indian investment destined to South-East Europe and CIS region. A total of 60 Indian parent companies are operating in Russia. Kazakhstan with US \$174 million of Indian investment and 11 parent Indian companies is the second largest host in the South-East Europe and CIS sub-region.

Although the sub-region of South-East Europe was the initial destination for Indian FDI in the South-East Europe and CIS region, however, it has received about 1 per cent of Indian FDI stock. South-East European countries such as Bosnia and Herzegovina, Bulgaria and Romania had attracted some Indian FDI projects but were not very substantial in terms of size.

Sectoral Trends. The primary sector principally led by gas and oil segment has been the largest host sector of Indian FDI in South-East Europe and CIS subregion. A total amount of US $\$ 1073$ million has been invested by two Indian companies in accessing gas and oil resources of two host countries, namely Russia and Kyrgyzstan (Appendix Table A8). This amounted to 77 per cent of total investment undertaken by Indian companies in this region. Other two economic sectors, manufacturing and service sector, each accounted for about 12 per cent share. Within the manufacturing sector, pharmaceuticals, chemicals and food and beverages are three important host sectors for Indian parent companies. Construction and engineering services is the most attractive service sector for Indian FDI in the South-East Europe and CIS region. 


\section{Ownership Structure}

The growth of Indian FDI in developing region has been accompanied by a marked structural change in the ownership choice of Indian parent companies over time, with a decline in the preference for joint ownership and a rise in that for fullownership in OFDI projects. In terms of ownership structure, Indian parent companies entering into developing region invariably opted for an ownership sharing with local companies in the 1960s and their strong preference for joint ownership continued in 1970s and 1980s. Indian firms during these periods had less experience in trans-border investment activities and possessed modest technological advantages derived from reverse engineering of foreign technologies. With these characteristics it is natural for Indian firm's to find joint venture as an attractive OFDI strategy to minimize the potential risks and liabilities that characterize global production. The JV partner provides additional finance, marketing intelligence, and information on local laws and institutions, which are crucial inputs for successful FDI projects by Indian companies. The contemporary home country OFDI policy regime also required the Indian parent companies to go for joint venture (JV) in host countries. All these factors had contributed to Indian firms' overwhelming choice for joint ownership mode in their OFDI operations until 1980s.

In spite of the prevailing choice for JVs over 1960-1980, the importance of WOS was growing over time. The share of wOS in total number of overseas approvals granted to Indian parent companies, which was zero per cent in 1961-1969 rose to 12 per cent in 1980-1989 (Appendix Table A9). By 1990-1999, the share of wos went up to 41 per cent and then outpaced that of JV in 2000-2007 to reach 72.3 per cent. Clearly, wOS become the most preferred form of OFDI strategy by Indian parent companies in early 2000s. The relaxation of policy restriction on the extent of ownership interest that Indian companies can hold in their overseas entities in 1990s has played a role. The growing firm-specific ownership advantages of Indian parent firms stemming from expanded technological and skill assets - created in-house and/or acquired abroad - has been the major driving factor behind the increased preference of Indian parent firms to have full-ownership in their OFDI projects. The risk of losing control over their technological assets is quite low in wOS strategy than in JV strategy. Moreover, the WOS strategy ensures that Indian service parent companies including software sector are able to provide the required high quality service delivery through a secure mode to global buyers (Pradhan, 2008 a). It also appears that with Indian parent firms gaining initial experience in OFDI in pre-1990s period are now more confident in their OFDI strategy to go alone and operate in host developing countries. 


\section{Overseas Acquisitions}

The flow of Indian FDI into developing region until recently was through establishment of new production entities owned jointly or wholly by Indian investing firms. The process of Indian FDI in developing region has, however, acquired a new dimension of late with a number of Indian firms adopting acquisition as an alternative strategy of market entry. During 2000-2008, a total of 110 Indian firms undertook 166 acquisitions in developing region related to buying of stake in foreign companies, their assets and product portfolio (Table 3). This aggregated to be as high as US \$12.4 billion worth of brownfield investment - an underestimated figure since many acquisition deals go without disclosing their financial consideration. The value of acquisitions made in developing region account for about 21 per cent of the total value of global acquisitions done by Indian firms in this period.

Developing region acquisitions by Indian firms are concentrated mainly in Asia (48 per cent of the total value and 58 per cent of the total number) and African region (28 per cent of the total value and 22 per cent of the total number) (Appendix Table A10). While neighbouring Asian countries offer enormous growth opportunities, African countries possess critical natural resources related to oil and gas. In terms of value of acquisition, South-East Europe and CIS with 20 per cent share is the next important host to Indian brownfield investment followed by Latin America and the Caribbean with just 4 per cent share.

Among individual host countries, Russia with US \$1741 million accounting for 14 per cent of the total developing region overseas acquisitions by Indian firms has emerged as the top destination mainly led by the ONGCs involvement in Sakhalin oilfield. Singapore with US \$1432 million worth of acquisition investment is the next important host developing country for Indian brownfield investment. Indonesia with US \$1407, Kenya with US \$1 273 million and Iran with US \$1 000 million are other important destinations for Indian firms' overseas acquisition activities in developing region.

In terms of value of acquisition, natural resources seeking activities seem to dominate the sectoral profile of Indian firms' acquisitions in developing region. Primary sector that includes oil, gas and mining activities accounts for about 60 per cent of Indian brownfield investment and has a total of 32 cases of acquisitions during 2000 to March 2008 (Appendix Table A10). Manufacturing is the next important sectoral host to Indian acquisitions. It accounted for 28.6 per cent of the value of acquisitions through a total of 78 acquisition deals. The share of 
TABLE 3. Developing Region Acquisitions by Indian Firms, 2000-2008

\begin{tabular}{|c|c|c|c|c|c|}
\hline \multirow{2}{*}{ Year } & \multicolumn{2}{|c|}{ Developing region acquisition } & \multicolumn{3}{|c|}{ In number } \\
\cline { 2 - 6 } & $\begin{array}{c}\text { Value (US\$ } \\
\text { million) }\end{array}$ & $\begin{array}{c}\text { As a per cent } \\
\text { of total Indian } \\
\text { acquisition }\end{array}$ & $\begin{array}{c}\text { Acquisition } \\
\text { Deals }\end{array}$ & $\begin{array}{c}\text { Acquiring } \\
\text { Indian firms }\end{array}$ & $\begin{array}{c}\text { Host } \\
\text { Developing } \\
\text { Countries }\end{array}$ \\
\hline 2000 & 21 & 2.3 & 4 & 2 & 4 \\
\hline 2001 & 22 & 11.4 & 2 & 2 & 2 \\
\hline 2002 & 2,483 & 95.4 & 8 & 3 & 7 \\
\hline 2003 & 21 & 3.4 & 7 & 6 & 5 \\
\hline 2004 & 2,228 & 73.9 & 19 & 15 & 14 \\
\hline 2005 & 1,558 & 38.2 & 37 & 28 & 26 \\
\hline 2006 & 1,727 & 22.4 & 38 & 36 & 15 \\
\hline 2007 & 3,271 & 8.8 & 44 & 37 & 19 \\
\hline 2008 & 1,019 & 28.1 & 7 & 7 & 6 \\
\hline All years & 12,350 & 20.7 & 166 & 110 & 46 \\
\hline
\end{tabular}

NOTE: Data for 2008 is from January to March.

Source: Dataset constructed from different reports from newspapers, magazines and financial consulting firms like Hindu Business Line, Economic Times, Financial Express, Business World, Grant Thorton India, etcetera.

service sector is just 6 per cent with 51 cases of acquisition. The motivation of Indian firms in the case of manufacturing and service sector is unlikely to be of strategic asset-seeking type with a few exceptions. Indian firms interested in acquiring intangible assets for operating in global market will choose innovationcentric developed region over developing countries who themselves are technology laggards. In majority of the cases, the main motivation for Indian firms seems to be market-seeking where acquiring Indian firms get access to an existing market, local brand name, distribution and marketing networks.

\section{Leading Indian Players in Developing Region}

The profile of India's largest outward investing Indian firms has changed sectorally and geographically over different time periods. There are only six outward investing Indian firms in 1960s. These firms are fully private owned and belong to a total of five large Indian business houses like Thapar (Ballarpur Industries), JK Singhania (Raymond Ltd.), Birla (Birla Bombay and Birla Corporation), Godrej (Godrej and Boyce Mfg. Company) and Shriram group (Jay Engineering). The existing policy restrictions on growth of large firms in domestic market like 
MRTP, FERA, licensing regime, etc., have forced these business groups to resort to OFDI as an alternative way of growth. OFDI activities of these firms, except Birla Bombay Private which invested, were confined to a single host country and cover a range of manufacturing activities. Moreover, all the host countries such as Kenya, Nigeria, Malaysia, Sri Lanka, and Uganda, except Thailand, are those which have presence of strong Indian origin population.

The majority of leading outward investing Indian firms in 1970s continued to be private owned by large business houses and have largely invested in the manufacturing sector. However, service sector public owned companies like Life Insurance Company started undertaking cross border investment. This company undertook direct investment for providing insurance services in Kenya. Besides, Thapar group has set up an overseas venture in another service sector, namely hotel and restaurant. Unlike in 1960s, the average number of host countries per investing Indian firms has gone up to two in 1970s.

The visibility of public owned companies among leading 10 outward investing firms in developing region improved considerably in 1980s. Public owned Indian companies such as General Insurance Corporation of India, Indian Farmers Fertilizers Co-Op (IFFCO), and Life Insurance Company ranked second, third and seventh important outward investing firms in this period. The sectoral profile of leading investors became more diversified - textile, fertilizers, glass, palm oil, agricultural products, engineering goods, pharmaceuticals, insurance and hotel. Beside market-seeking motivation, raw material sourcing has emerged as another driving factor for investment by leading Indian firms. For example, sourcing phosphoric acid and palm oil respectively were the motivating factors behind IFFCO's investment in Senegal and that of Ballarpur Industries in Malaysia. The number of host countries per investing Indian firm has gone up to three in the case of four leading outward investing Indian firms and four host countries for another leading company.

The 1990s has witnessed the rise of two natural resource-seeking Indian companies to be among leading outward investors. Private owned Reliance Industries and public owned Indian Oil Corporation respectively claimed $4^{\text {th }}$ and $6^{\text {th }}$ positions in the list of top 10 Indian investing firms in developing region with operation in oil refinery and exploration. In 2000-2007, ONGC emerged as the top outward investing firm. This government owned company is now operating in the hydrocarbon and natural gas sector of as many as 12 developing countries. In this period, two Indian telecommunication service providers, namely Videsh Sanchar Nigam and Reilance Infocom occupied $4^{\text {th }}$ and $7^{\text {th }}$ positions among large outward 
investing Indian companies. This shows that Indian service OFDI, which emerged from the insurance and hotel sectors since 1970s is being joined by new players from other service firms belonging to telecommunication sector.

The analysis of the changing profile of leading Indian outward investors shows that large business houses continued to dominate the list of top outward investing Indian companies, but a number of government owned enterprises have been quite visible in recent periods. It appears that the leading Indian parent companies are now more confident in their OFDI operation and are capable of managing their overseas activities in multiple countries as opposed to a single host country in 1960s. Although the main motivation of leading outward investing firms in initial period was accessing the overseas market, other objectives like accessing raw materials and natural resources like oil and gas can be discernable in subsequent periods. Apart from diversifying the nature of their manufacturing activities, OFDI from leading firms are being increasingly led by a wide range of service activities from financial and insurance services to hotel and telecommunication services.

\section{MAIN DRIVERS OF INDIAN FDI}

Considering the phenomenal growth of developing region oriented Indian FDI since 1990 s, it is important to understand the factors that are behind the transborder expansion of Indian enterprises. Drivers and determinants of Indian OFDI directed at developing region can be argued to be quite different between the periods 1960-1980 and 1990s onward.

Although Indian FDI was predominantly destined to developing region in pre-1990s period, the number of investing Indian companies and size of their investment was small. In this period involvement of Indian firms in developing region through OFDI was limited to a small group of large business conglomerate houses like Birla, Tata, Thapar, JK Singhania, Mafatlal, Kirloskar, United Breweries, etc. These enterprises were forced to seek trans-border market due to policy-led barriers on their growth in the domestic market. The system of industrial licensing, Monopolies and Restrictive Trade Practices (MRTP) Act, Foreign Exchange Regulation Act (FERA), reservation of large-scale industrial areas for public and small-scale sector, etc., have seriously prevented their expansion in the home market, leading to a business strategy of outward investment. ${ }^{5}$ Given

\footnotetext{
${ }^{5}$ A small group of Indian business houses categorized as MRTP houses accounted for nearly about 83 per cent of actual Indian OFDI stock as at the end of 1982 and their share has declined to 65.6 per cent at the end of 1987 (Ranganathan, 1990). So, clearly the largest chunk of Indian economy
} 
the formative stage of their firm-specific capability building and modest intangible advantages, these Indian firms could only target developing region, which has similar factor and business conditions like India. Indian firms were enhancing their technological capability from a variety of means - reverse engineering of imported products, equipment and machineries, buying of foreign technologies and doing adaptive and incremental in-house research and development (R\&D) but were still lacking broad-based technological assets to be aggressively engaged in foreign production activities.

The lack of participation of small and medium-sized enterprises and many other large non-MRTP Indian companies in Indian OFDI flows directed at developing region has been largely driven by the contemporary inward-looking development policies pursued by the home country. These policies marked by strong barriers to imports and severe restriction on entry of foreign companies have adversely affected the propensity of majority of Indian companies to participate in the world market, either through exports or OFDI. Another determining factor for low level of Indian OFDI and smaller number of outward investing Indian firms in developing region was the pursuance of a restrictive OFDI policy by India (Pradhan, 2008a). Indian firms desirous of undertaking OFDI were not allowed to do so through cash transfer, but only in the form of exporting Indian made machinery, equipment and know-how. Indian investing firms were discouraged to hold majority ownership in their OFDI projects and the approval procedures for OFDI projects were extremely cumbersome.

Although Indian OFDI policy in pre-1990s period was in general a restrictive one, it had a strong positive bias towards developing countries. In keeping with the philosophy of South-South Cooperation Indian policy makers wanted to promote Indian FDI into developing countries. Many of the restrictive clauses like promotion of JV mode of Indian FDI was inspired by the realization that Indian FDI should not operate in similar manner as developed region FDI operate in host developing countries. A JV form ensures that Indian FDI becomes an effective means of sharing India's development experience with fellow developing countries. Many host developing countries had a cordial attitude towards FDI projects from developing countries like India. This has also influenced many outward investing Indian firms to get involved in developing region where they are treated favourably than their developed country counterparts.

consisting of Indian non-MRTP private companies and small- and medium-sized enterprises did not participate in OFDI process directed at developing countries during 1960-1980. 
Since 1990s the underlying forces of Indian OFDI into developing region has changed significantly. Abolition of non-tariff barriers and large scale reduction in tariff across industrial products has infused greater external competition into Indian market. Allowing foreign companies into India under automatic route with 100 per cent ownership in almost all areas of productive operation, except a small negative list, has further intensified competitive pressures on Indian firms hitherto concentrating on domestic markets. These competitive pressures led to a turning point in the outward orientation of Indian firms and OFDI emerged as a preferred strategy for survival. Indian domestic firms across sizes - small, medium and large - resorted to OFDI as a means of survival and growth in a globalized business environment (Pradhan and Sahu, 2007). In this context, developing region and particularly neighbouring countries with familiar socio-economic environment seem to be the first natural choice for recently internationalizing Indian domestic firms. Entry into intraregional developing countries is relatively less risky a strategy for firms new to internationalization than entering into fiercely competitive non-familiar markets in developed region.

Since 1990s a number of natural resource-based Indian enterprises emerged to explore developing region for accessing relevant resources. The growing global competition for securing natural resources like oil, gas and minerals has forced Indian government-owned firms like ONGC, Oil India, Hindustan Petroleum Corporation Limited, etc., to undertake resource-seeking investment abroad. Many privately-owned enterprises like Reliance, Gujarat NRE Cook, Hindalco Industries, Tata Steel, etc., started investing in many natural resource rich developing countries.

The liberalization of OFDI policy regime in the 1990s that has virtually lifted any ceiling on outward investment, permitted cash transfer, and encouraged overseas acquisitions, has led to a watershed in the history of India's international production. For large Indian companies that significantly improved their ownership advantages by innovating cost-effective processes and undertaking high $R \& D$ expenses for product developments, quality and skill improvements, OFDI came as a natural choice for becoming a multinational entity. In their globalization strategy, developing region continued to receive attention although developed region with large market is relatively more attractive. 


\section{DEVELOPMENT IMPACTS ON HOST DEVELOPING COUNTRIES}

The developmental role of Indian FDI in host developing region crucially depends upon the average quality of FDI projects undertaken by Indian firms. The benefits of Indian FDI projects can vary by six quality dimensions involving sectoral composition, nature of value-added activities, market-orientation, ownership participation, the relevance of technology transfer and extent of local knowledge creation activities (see Pradhan, 2006 for more on the concept of FDI quality). The following discussion will consider these quality aspects of Indian FDI to infer about their likely impact on the development process of developing countries.

Sectoral dimension. The developmental role of Indian FDI, inter alia, is dependent upon the type of sectors where much of Indian FDI projects have gone into host developing region. Indian FDI in mining, natural resource extraction and labour-intensive manufacturing activities offers limited opportunities for growth, employment and knowledge-spillovers. Developing host countries that possess inadequate domestic capabilities in knowledge-based manufacturing activities would benefit significantly if Indian firms operate in such segment of the host economy. The empirical evidence on the sectoral composition of Indian FDI flows into developing region as discussed before suggests that Indian investing firms possess a highly diversified sectoral portfolio. The primary sector accounted for 16.8 per cent, 36 per cent, 11 per cent, and 80 per cent in the total Indian FDI flows that went respectively into Africa, Latin America, Asia and South-East Europe and CIS countries. Except the South-East Europe and CIS region, majority of Indian FDI has gone into either manufacturing or service sectors like finance, telecommunication and software services. Apart from traditional labour-intensive industries like food processing, textile and leather, Indian firms have been operating in knowledge-intensive manufacturing activities like chemicals, pharmaceuticals, transport equipment and machinery and equipment. This sectoral pattern of Indian FDI flows with a well representation of technology-intensive industries suggests that Indian FDI involve better quality projects that have a large potential for generating knowledge-spillovers within host developing countries.

Nature of value-added activities. Indian FDI projects not withstanding their concentration in technology-intensive manufacturing and service sectors may involve narrow developmental impact unless they are into the right kind of value-added activities. An FDI project that generates all its value-added through marketing and 
distribution of products exported from India is clearly of low quality than another FDI project that leads to value addition through local production and marketing in the host developing countries. The nature of value-added activities of Indian FDI appear to be of fairly good quality. As on $1^{\text {st }}$ July 1982, Indian enterprises undertook a total of 138 OFDI projects for manufacturing and marketing in the host countries as compared to only 27 OFDI projects exclusively meant for trading and marketing activities (FICCI, 1982). The number of manufacturing FDI projects amount to a quintuple of those of trading OFDI projects. This suggests that Indian OFDI flows during 1960-1970 were mostly for locally producing the products in host countries. The available information for recent years indicates that this nature of Indian FDI seems to have changed little over time. It has been found that the volume of Indian investment associated with manufacturing projects (US \$3 billion) is nearly 17-times higher than the amount of investment related to projects for trading purposes (US \$179 million) during May 2001 to September 2002. However, the difference between manufacturing and trading Indian investment is likely to vary greatly by individual industries but information at disaggregate level is not available. The available information for two industries such as pharmaceuticals and textile suggest that the value of manufacturing OFDI flows from them respectively is US \$61.3 million and US \$5.3 million. This would suggest that Indian FDI projects from pharmaceutical sector is of better quality ( $\$ 61.3$ million manufacturing OFDI flows as compared to \$24.9 million trading OFDI flows) whereas that from textile sector is of low quality ( $\$ 5.3$ million of manufacturing OFDI flows as compared to $\$ 11.6$ million of trading OFDI flows).

Market-orientation. Market focus of Indian FDI project is another quality aspect which needs a close look for appreciating their role in the development of host developing countries. Domestic market-seeking Indian FDI projects as compared to export-oriented projects are likely to be low quality as they tend to crowd-out domestic competitors in labour-intensive industries and possess limited scope for knowledge-spillovers and local linkage generation. While data limitation on the export-orientation of Indian foreign affiliates makes it difficult to explore marketorientation aspect of Indian FDI, the scope of export platform FDI from India appears to be limited. There are some cases of Indian FDI in Nepal and Sri Lanka where Indian subsidiaries are exporting their products into India but motivation of Indian investing firms using other host developing countries as export bases may not be very strong. Indian greenfield manufacturing projects in developing region are mostly of local market-seeking variety. 
Ownership participation. The relevance and efficacy of Indian FDI in developing countries has also to be gauged in terms of the magnitude of ownership held by Indian parent companies in their overseas ventures. Knowledge and skills that Indian FDI project carry have a greater scope for diffusion in cases where Indian investing companies tend to share ownership with host country entrepreneurs. Given this reason, host developing countries may not consider fully-owned Indian FDI projects as useful when compared to Indian joint venture projects. The empirical evidence discussed elsewhere indicates that Indian parent companies in most of the OFDI projects had shared the responsibility of management with local parties in pre-1990s period. However, recently since 1990s Indian investing companies preferred full ownership of their overseas units. This fact would imply that overtime the quality of Indian FDI projects measured by ownership participation for host developing countries is effectively getting reduced.

Appropriateness of technology. The appropriateness of technologies associated with inward FDI in host developing region has been a long debated issue in the development literature. One strand of thought on the subject sees developing country FDI projects as a source of intermediate technologies that is well suited to the needs and requirements of host developing countries. Since FDI projects originating within developing region are assumed to involve labour-intensive technologies, they are more relevant to capital scarce and labour abundant developing countries. This characterization of developing country FDI projects fits reasonably well with the character of Indian FDI during 1960s-1980s. Largest concentration of Indian FDI flows were in sectors with relatively simple/well diffused technologies, low intensity of product differentiation, and utilizing relatively labour-intensive technologies (Lall, 1983). Under the import-substitution industrialization strategy, both the public-owned and privately controlled Indian firms were encouraged to enhance their indigenous technological capabilities by innovating small-scale production technologies for imported product designs, scaling down of plants and adaptation of foreign technologies to local raw materials and factor conditions (Desai, 1984). A number of Indian firms succeeded in developing adapted foreign technologies and later transferred them to other low-wage developing countries with small domestic markets. The small-scale production and labour-intensive technologies transferred by Indian parent companies were quite suitable to the development requirements of host developing countries in that period.

However, the current phase of globalization appears to have induced significant changes in the nature of technological assets possessed by international- 
izing Indian parent firms. Given the past technological capability building under a process patent regime and facilitative public policies, a number of Indian companies started rapidly emerging from knowledge and scale-intensive sectors with differentiated marketing requirements in 1990s (Pradhan, 2008 a, 2008 b). The competitive pressures generated by the extensive liberalization measures that India undertook in the last fifteen years or so have further forced Indian firms to upgrade their technological activities.

By the early 2000s, the technological profile of Indian firms from pharmaceuticals, chemicals, biotechnologies, and automotive sectors has substantially transformed from mere adaptors of foreign technologies to be creators of substantial technological assets of their own. The relatively leading Indian pharmaceutical companies like Dr. Reddy'S Laboratories, Matrix Laboratories, Ranbaxy Laboratories, Venus Remedies, Wockhardt, Strides Arcolab, Ind-Swift Laboratories, Dabur Pharma etc. that used to spent minimal proportion of sales in their in-house R\&D activities in early 1990s are currently devoting more than 9 per cent of their sales. The R\&D expenditure of Indian automotive firms shifted to a rapid growth path in last seven years (Pradhan and Singh, 2008) with a growing number of firms attaining higher R\&D intensities of 2-5 per cent and a few others achieving more than 8 per cent. Tata Motor's car models Indica (1999) and Nano (2008) and Mahindra \& Mahindra's multi-utility vehicle Scorpio (2002) clearly demonstrate the product capabilities that large Indian vehicle manufacturers have achieved over time. Indian information technology firms have been global leaders in innovating industry-specific frontier technologies and new products. In a number of industries, large-sized Indian firms not only graduated towards product development based on in-house R\&D efforts, but also started acquiring large number of foreign companies representing new products, skills and technologies.

When large Indian firms are significantly upgrading their technological capabilities embedded in intensive automatic mechanization of manufacturing process, often they represent technologies used in the industrialized countries. Apparently the technologies that are being transferred by these Indian investing companies through OFDI in the current period underlined a more complex technological process and hence are likely to be far away from the initial portrayals as being intermediate and appropriate to the requirements of host developing countries. However, small and medium-sized Indian companies that are now transnationalizing into southern countries can normally be expected to be a source of intermediate technologies. 
Local knowledge creation. There are no statistics available on the R\&D activities of Indian foreign affiliates. However, it can be argued that the chances of Indian companies investing in developing countries for doing R\&D activities are very remote. The contribution of foreign affiliates of Indian firms in local technology creation can be believed to be minimal except minor investments in adapting Indian technologies to the local conditions and troubleshooting. However, Indian firms are likely to provide training to local employees of their overseas affiliates in the initial period for the successful operation of production process. In the 1970s Indian OFDI policy had a compulsory training provision to be imparted by Indian parent companies to their joint venture collaborators. However, such provision do not exist now.

It is evident from the above discussion that the nature and relative significance of Indian FDI for host developing countries vary among different indicators of quality. Indian FDI projects are of good quality as far as they are more for local manufacturing as opposed to trading purposes and are also into knowledge-intensive sectors. Moreover, Indian FDI represents financial and knowledge resources with scope for knowledge-spillovers. However, the benefits of Indian FDI project seem to be narrowing down considering the fact that Indian investing firms have been progressively opting for wholly-owned entities as opposed to joint ventures and their technological assets are getting complex and very advance. Indian foreign affiliates are believed to incur little R\&D expenses and whatever technologies they are receiving from their Indian parents are likely to be beyond the initial categorization of intermediate technologies from the development perspective of host developing countries. Further, Indian FDI in developing countries is unlikely to possess any strong motivation for export activities.

\section{Conclusions}

Indian enterprises are pioneers among firms based in developing region to undertake direct investment activities in fellow developing countries. The volume of Indian investment and the number of investing Indian parent companies in developing region has gone up significantly since 1990s. This rise in Indian investment across different developing sub-regions and countries is partly contributed by growing competition in Indian markets through cheap imports and entry of foreign firms and the motivation of technologically capable large Indian firms to expand into overseas market. Liberalization of Indian policies with regard to outward FDI, industry, technology, etc., have all contributed their bit to 
the increased Indian FDI activity in developing region. Regionally Indian FDI covers a total of 92 developing countries but substantial amount of investment has gone into intra-regional host countries (i.e. Asian countries), followed by Africa, South-East Europe and CIS and Latin America. Indian investment is widely spread across sectors, from manufacturing to services. Since 1990s, the amount of Indian FDI in natural resources covering oil, gas and minerals has gone up significantly propelled by the strategic energy security issues and mostly led by public-owned companies.

In a general sense, the growing flows of Indian FDI into developing region would be mostly development promoting by relaxing financial and knowledge resource constraints faced by host countries. Besides developing countries FDI projects are more valuable to host developing countries than FDI projects from developed countries because they involve joint venture form of businesses and possess intermediate technologies with enormous positive social and economic impacts. These two characteristics of developing country multinationals are well fitted for developing region bound Indian FDI in pre-1990s period. However, with the growing complexities of the in-house innovation and technological activities of Indian parent firms and large scale acquisition of foreign technologies, it makes the assumption of intermediate technologies untenable. As Indian investing firms are increasingly going for wholly-owned FDI projects in developing countries, there is no direct spread of transferred technologies to local parties, but only through potential spillover channels. It is also less likely that Indian firms are investing in developing region for doing R\&D and performing substantial export activities.

However, there are certain positive characteristics of Indian FDI for host developing countries. Since Indian multinationals are involved not only in primary sector and labour-intensive industries, but also in knowledge-based sectors, their presence may play a catalytic role in the development of technologyintensive industries of host countries. This is also because Indian investing firms are more willing to produce the products and services locally than just perform marketing operations.

To conclude, there are costs and benefits of Indian firms operating in developing countries and the net developmental impact would vary across host countries and sectors. Host governments may need to examine Indian FDI projects from the angle of their development objectives and prudently encourage right quality of Indian FDI into their sectors for maximizing benefits. 
38 ECONOMÍA: TEORÍA Y PRÁCTICA • Nueva Época, número 29, julio-diciembre 2008

\section{APPENDIX}

TABLE A1. Indian FDI Flows into Africa, by Destination, 1961-2007

\begin{tabular}{|c|c|c|c|c|c|c|c|c|}
\hline \multirow{3}{*}{ Region/Country } & \multicolumn{7}{|c|}{ FDI flows in \$ million } & \multirow{3}{*}{$\begin{array}{c}\text { Number of } \\
\text { Investing } \\
\text { Firms }\end{array}$} \\
\hline & \multirow{2}{*}{ 1961-1969 } & \multirow{2}{*}{ 1970-1979 } & \multirow{2}{*}{ 1980-1989 } & \multirow{2}{*}{ 1990-1999 } & \multirow{2}{*}{ 2000-2007 } & \multicolumn{2}{|c|}{ All years } & \\
\hline & & & & & & Value & Per cent & \\
\hline Africa & 13 & 35 & 25 & 317 & 2968 & 3358 & 100 & 398 \\
\hline North Africa & & & 1 & 41 & 508 & 550 & 16.37 & 23 \\
\hline Algeria & & & & & 1 & 1 & 0.04 & 3 \\
\hline Egypt & & & 1 & 8 & 7 & 16 & 0.47 & 14 \\
\hline Libya & & & & & 100 & 100 & 2.99 & 3 \\
\hline Morocco & & & & 32 & & 32 & 0.97 & 1 \\
\hline Sudan & & & & & 395 & 395 & 11.75 & 3 \\
\hline Tunisia & & & & & 5 & 5 & 0.16 & \\
\hline West Africa & 3 & 4 & 19 & 29 & 203 & 258 & 7.69 & 49 \\
\hline Burkina Faso & & & & & 0.05 & 0.05 & 0.00 & 1 \\
\hline Cote-d'Ivoire & & & & 0.01 & 14 & 14 & 0.43 & 4 \\
\hline Ghana & & & & 0.05 & 2 & 2 & 0.07 & 6 \\
\hline Liberia & & & & 0.3 & 155 & 155 & 4.62 & 2 \\
\hline Niger & & & & & 0.01 & 0.01 & 0.00 & 1 \\
\hline Nigeria & 3 & 4 & 4 & 7 & 30 & 47 & 1.41 & 34 \\
\hline Senegal & & & 16 & 22 & 1 & 39 & 1.16 & 2 \\
\hline Sierra Leone & & & & & 0.02 & 0.02 & 0.00 & 2 \\
\hline Central Africa & & & & & 63 & 63 & 1.88 & 2 \\
\hline Congo & & & & & 0.2 & 0.2 & 0.01 & 1 \\
\hline Gabon & & & & & 63 & 63 & 1.88 & 1 \\
\hline East Africa & 10 & 31 & 5 & 226 & 2170 & 2442 & 72.70 & 295 \\
\hline Ethiopia & & & 0.03 & & 5 & 5 & 0.16 & 12 \\
\hline Kenya & 9 & 27 & 0.7 & 13 & 3 & 53 & 1.56 & 26 \\
\hline Mauritius & & & 0.4 & 201 & 2149 & 2351 & 70.00 & 233 \\
\hline Mozambique & & & & 0.3 & 10 & 10 & 0.31 & 2 \\
\hline Seychelles & & 4 & 2 & & & 5 & 0.16 & 2 \\
\hline Tanzania & & & & 4 & 1 & 5 & 0.14 & 10 \\
\hline Uganda & 0.9 & & & 4 & 0.2 & 5 & 0.15 & 11 \\
\hline Zambia & & & 2 & 2 & 0.2 & 5 & 0.14 & 6 \\
\hline Zimbabwe & & & 0.1 & 1 & 1 & 3 & 0.08 & 4 \\
\hline Southern Africa & & & & 22 & 24 & 45 & 1.35 & 50 \\
\hline Botswana & & & & 0.2 & 1 & 1 & 0.04 & 7 \\
\hline Namibia & & & & 0.3 & 0.1 & 0.38 & 0.01 & 3 \\
\hline South Africa & & & & 21 & 22 & 44 & 1.30 & 41 \\
\hline
\end{tabular}

Note and source: Same as Table 1. 
TABLE A2. Sectoral Composition of Indian FDI Flows into Africa, 1961-2007

\begin{tabular}{|c|c|c|c|c|c|c|c|c|c|}
\hline \multirow{3}{*}{ Industry } & \multicolumn{7}{|c|}{ FDI flows in \$ million } & \multirow{3}{*}{$\begin{array}{l}\text { No. } \\
\text { of } \\
\text { firms }\end{array}$} & \multirow{3}{*}{$\begin{array}{c}\text { No. of } \\
\text { countries }\end{array}$} \\
\hline & \multirow{2}{*}{$\begin{array}{l}1961- \\
1969\end{array}$} & \multirow{2}{*}{$\begin{array}{l}1970- \\
1979\end{array}$} & \multirow{2}{*}{$\begin{array}{l}1980- \\
1989\end{array}$} & \multirow{2}{*}{\begin{tabular}{|l}
$1990-$ \\
1999
\end{tabular}} & \multirow{2}{*}{$\begin{array}{l}2000- \\
2007\end{array}$} & \multicolumn{2}{|c|}{ All years } & & \\
\hline & & & & & & Value & Per cent & & \\
\hline Primary & & & & 23 & 594 & 617 & 18.38 & 24 & 13 \\
\hline Agriculture \& allied products & & & & 7 & 18 & 25 & 0.74 & 10 & 5 \\
\hline Ores \& minerals & & & & 0.3 & 0.1 & 0.4 & 0.01 & 6 & 6 \\
\hline Gas, Petroleum and related products & & & & 16 & 576 & 592 & 17.63 & 8 & 6 \\
\hline Manufacturing & 13 & 27 & 21 & 259 & 1556 & 1877 & 55.88 & 225 & 23 \\
\hline Food, beverages and tobacco & & & 1 & 18 & 23 & 42 & 1.25 & 21 & 9 \\
\hline Textiles and wearing apparel & 10 & 0.29 & 0.05 & 16 & 34 & 60 & 1.80 & 25 & 10 \\
\hline Paper and paper products & & 23 & & 0.3 & 2 & 25 & 0.75 & 4 & 3 \\
\hline Printing and publication & & & & & 1 & 1 & 0.03 & 5 & 4 \\
\hline Gems and jewellery & & & & 2 & 17 & 19 & 0.57 & 12 & 5 \\
\hline Leather and related products & & & & 19 & 0.2 & 20 & 0.58 & 6 & 2 \\
\hline Rubber and plastic products & & & & 3 & 263 & 266 & 7.91 & 19 & 7 \\
\hline Non-metallic mineral products & & 2 & & 4 & 0.1 & 6 & 0.18 & 7 & 5 \\
\hline Basic metals and fabricated metal product & & & & 14 & 60 & 74 & 2.20 & 23 & 9 \\
\hline Machinery and equipment & & 2 & 0.3 & 2 & 54 & 58 & 1.74 & 20 & 9 \\
\hline Electrical machinery and equipment & 3 & 0.03 & 0.2 & 7 & 4 & 15 & 0.43 & 21 & 6 \\
\hline Transport equipment & & 0.2 & & 6 & 119 & 125 & 3.71 & 9 & 6 \\
\hline Computer, electronic, medical, precision & & & & 3 & 41 & 44 & 1.31 & 15 & 4 \\
\hline Chemicals & & & 16 & 137 & 930 & 1083 & 32.25 & 24 & 9 \\
\hline Pharmaceuticals & & 0.3 & 1 & 9 & 8 & 18 & 0.52 & 35 & 11 \\
\hline Other manufacturing & & & 2 & 19 & 1 & 22 & 0.66 & 7 & 3 \\
\hline Services & & 8 & 3 & 32 & 817 & 860 & 25.59 & 163 & 17 \\
\hline Construction and engineering services & & 0.3 & & 1 & 28 & 29 & 0.87 & 15 & 5 \\
\hline Trading & & & 2 & 6 & & 8 & 0.24 & 9 & 7 \\
\hline Advertising and market research & & & & 0.00 & 4 & 4 & 0.12 & 6 & 1 \\
\hline Consultancy and business advisory service & & 0.1 & 0.1 & 0.01 & 3 & 3 & 0.10 & 15 & 5 \\
\hline Event management & & & & & 0.3 & 0.3 & 0.01 & 2 & 1 \\
\hline Film, entertainment and broadcasting & & & & 1 & 60 & 61 & 1.82 & 14 & 1 \\
\hline Hospitality and tourism & & 4 & 0.2 & 1 & 0.2 & 5 & 0.16 & 6 & 5 \\
\hline Hospital and health services & & & & & 2 & 2 & 0.04 & 1 & 2 \\
\hline Financial and insurance services & & 4 & 0.1 & 19 & 229 & 251 & 7.48 & 43 & 8 \\
\hline Telecommunication services & & & & 0.01 & 5 & 5 & 0.14 & 3 & 1 \\
\hline Transportation services & & & 1 & 4 & 162 & 167 & 4.97 & 14 & 4 \\
\hline Software development, packages and ITES & & & & 0.07 & 323 & 323 & 9.63 & 44 & 4 \\
\hline Other services & & & & & 0.4 & 0.4 & 0.01 & 6 & 4 \\
\hline Others & & & 2 & 3 & 0.3 & 5 & 0.14 & 12 & 5 \\
\hline Total & 13 & 35 & 25 & 317 & 296 & 3358 & 100 & 398 & 28 \\
\hline
\end{tabular}

Note and source: Same as Table 1. 
40 ECONOMÍA: TEORÍA Y PRÁCTICA • Nueva Época, número 29, julio-diciembre 2008

TABLE A3. Indian FDI Flows into Latin America and Caribbean, by Destination, 1980-2007

\begin{tabular}{|c|c|c|c|c|c|c|}
\hline \multirow{3}{*}{ Region/Country } & \multicolumn{5}{|c|}{ FDI flows in $\$$ million } & \multirow{3}{*}{$\begin{array}{c}\text { Number of } \\
\text { investing firms }\end{array}$} \\
\hline & \multirow{2}{*}{$1980-1989$} & \multirow{2}{*}{ 1990-1999 } & \multirow{2}{*}{$2000-2007$} & \multicolumn{2}{|c|}{ All years } & \\
\hline & & & & Value & Per cent & \\
\hline Latin America and Caribbean & 0.2 & 47 & 1132 & 1179 & 100 & 61 \\
\hline South America & & 19 & 514 & 533 & 45.19 & 27 \\
\hline Argentina & & 0.3 & & 0 & 0.03 & 1 \\
\hline Brazil & & 3 & 479 & 481 & 40.81 & 23 \\
\hline Colombia & & 16 & & 16 & 1.38 & 1 \\
\hline Guyana & & 0.2 & & 0.2 & 0.01 & 1 \\
\hline Peru & & & 0.1 & 0.1 & 0.01 & 2 \\
\hline Uruguay & & & 35 & 35 & 2.96 & 1 \\
\hline Central America & 0.2 & 9 & 86 & 95 & 8.04 & 22 \\
\hline Belize & & 0.4 & & 0.4 & 0.03 & 1 \\
\hline Honduras & & & 0.3 & 0.3 & 0.03 & 1 \\
\hline Mexico & & 5 & 62 & 68 & 5.75 & 10 \\
\hline Panama & 0.2 & 3 & 23 & 26 & 2.23 & 10 \\
\hline Caribbean and Other America & & 19 & 533 & 551 & 46.77 & 18 \\
\hline Bahamas & & 1 & 0.1 & 1 & 0.09 & 5 \\
\hline Bermuda & & 16 & 515 & 531 & 45.01 & 9 \\
\hline Cuba & & & 17 & 17 & 1.44 & 1 \\
\hline St. Vincent & & & 0.1 & 0.1 & 0.00 & 1 \\
\hline Trinidad and Tobago & & 2 & 1 & 3 & 0.23 & 2 \\
\hline
\end{tabular}

Note and source: Same as Table 1. 
TABLE A4. Sectoral Composition of Indian FDI Flows into Latin America, 1980-2007

\begin{tabular}{|c|c|c|c|c|c|c|c|}
\hline \multirow{3}{*}{ Industry } & \multicolumn{5}{|c|}{ FDI flows in $\$$ million } & \multirow{3}{*}{$\begin{array}{l}\text { Number } \\
\text { of firms }\end{array}$} & \multirow{3}{*}{$\begin{array}{c}\text { Number } \\
\text { of } \\
\text { countries }\end{array}$} \\
\hline & \multirow{2}{*}{$\begin{array}{c}1980- \\
1989\end{array}$} & \multirow{2}{*}{$\begin{array}{c}1990- \\
1999\end{array}$} & \multirow{2}{*}{$\begin{array}{l}2000- \\
2007\end{array}$} & \multicolumn{2}{|c|}{ All years } & & \\
\hline & & & & Value & Per cent & & \\
\hline Primary & & 0.3 & 427 & 427 & 36.24 & 2 & 3 \\
\hline Agriculture $\&$ allied products & & 0.3 & & 0.3 & 0.03 & 1 & 1 \\
\hline Gas, petroleum and related products & & & 427 & 427 & 36.22 & 1 & 2 \\
\hline Manufacturing & 0.1 & 9 & 151 & 160 & 13.57 & 34 & 7 \\
\hline Food, beverages and tobacco & & & 20 & 20 & 1.71 & 2 & 2 \\
\hline Textiles and wearing apparel & & 0.02 & 0.3 & 0.3 & 0.03 & 2 & 2 \\
\hline Gems and jewellery & & & 9 & 9 & 0.76 & 1 & 1 \\
\hline Rubber and plastic products & & & 0.3 & 0.3 & 0.03 & 3 & 2 \\
\hline Non-metallic mineral products & & 0.4 & & 0.4 & 0.03 & 1 & 1 \\
\hline Basic metals and fabricated metal product & & 5 & 0.4 & 6 & 0.49 & 3 & 2 \\
\hline Machinery and equipment & & & 1 & 1 & 0.06 & 2 & 1 \\
\hline Electrical machinery and equipment & & 1 & 0.1 & 1 & 0.09 & 3 & 2 \\
\hline Transport equipment & 0.1 & & & 0.1 & 0.01 & 1 & 1 \\
\hline Computer, electronic, medical, precision & & & 8 & 8 & 0.71 & 3 & 2 \\
\hline Chemicals & & 0.1 & & 0.1 & 0.01 & 2 & 2 \\
\hline Pharmaceuticals & & 3 & 111 & 114 & 9.65 & 15 & 3 \\
\hline Other manufacturing & & & 0.1 & 0.1 & 0.00 & 1 & 1 \\
\hline Services & 0.1 & 37 & 554 & 592 & 50.19 & 26 & 10 \\
\hline Construction and engineering services & & 17 & & 17 & 1.45 & 2 & 2 \\
\hline Consultancy and business advisory service & & 0.01 & 1 & 1 & 0.05 & 2 & 2 \\
\hline Hospital and health services & & & 1 & 1 & 0.10 & 1 & 1 \\
\hline Financial and insurance services & 0.1 & 2 & & 2 & 0.20 & 3 & 3 \\
\hline Telecommunication services & & & 215 & 215 & 18.24 & 2 & 2 \\
\hline Transportation services & & 2 & 3 & 5 & 0.40 & 4 & 2 \\
\hline Software development, packages and ITES & & 16 & 335 & 351 & 29.75 & 12 & 5 \\
\hline Others & & & 0.003 & 0.003 & 0.00 & 1 & 1 \\
\hline Total & 0.2 & 47 & 1132 & 1179 & 100 & 61 & 15 \\
\hline
\end{tabular}

Note and source: Same as Table 1. 
42 ECONOMÍA: TEORÍA Y PRÁCTICA • Nueva Época, número 29, julio-diciembre 2008

TABLE A5. Indian OFDI Flows into Asia and Oceania, by Destination, 1961-2007

\begin{tabular}{|c|c|c|c|c|c|c|c|c|}
\hline \multirow{3}{*}{ Region/Country } & \multicolumn{7}{|c|}{ FDI flows in \$ million } & \multirow{3}{*}{$\begin{array}{c}\text { Number of } \\
\text { investing } \\
\text { firms }\end{array}$} \\
\hline & \multirow{2}{*}{ 1961-1969 } & \multirow{2}{*}{ 1970-1979 } & \multirow{2}{*}{ 1980-1989 } & \multirow{2}{*}{ 1990-1999 } & \multirow{2}{*}{ 2000-2007 } & \multicolumn{2}{|c|}{ All years } & \\
\hline & & & & & & Value & Per cent & \\
\hline Asia \& Oceania & 9 & 46 & 61 & 1445 & 3407 & 4968 & 100 & 1298 \\
\hline West Asia & & 1 & 8 & 520 & 703 & 1232 & 24.79 & 413 \\
\hline Bahrain & & & 5 & 10 & 3 & 17 & 0.35 & 25 \\
\hline Iran & & & 0.1 & 60 & 45 & 105 & 2.12 & 11 \\
\hline Jordan & & & 0.2 & 15 & & 15 & 0.30 & 4 \\
\hline Kuwait & & & & 12 & 2 & 14 & 0.28 & 7 \\
\hline Oman & & & 0.3 & 141 & 102 & 243 & 4.89 & 31 \\
\hline Qatar & & & & & 16 & 16 & 0.32 & 3 \\
\hline Saudi Arabia & & 1 & 1 & 42 & 24 & 67 & 1.35 & 20 \\
\hline Syrian Arab Republic & & & & & 9 & 9 & 0.19 & 1 \\
\hline Turkey & & & & 0.1 & 0.4 & 0.5 & 0.01 & 3 \\
\hline UAE & & 1 & 2 & 240 & 502 & 744 & 14.98 & 335 \\
\hline East Asia & & 0.1 & 0.02 & 470 & 548 & 1018 & 20.50 & 181 \\
\hline China & & & & 27 & 188 & 214 & 4.32 & 60 \\
\hline Hong Kong & & 0.07 & 0.02 & 443 & 307 & 749 & 15.08 & 120 \\
\hline Mongolia & & & & 0.1 & & 0.1 & 0.00 & 1 \\
\hline North Korea & & & & & 52 & 52 & 1.04 & 1 \\
\hline South Korea & & & & 1 & 2 & 3 & 0.06 & 6 \\
\hline Taiwan & & & & & 0.3 & 0.3 & 0.01 & 2 \\
\hline South Asia & 0.05 & 5 & 15 & 170 & 151 & 341 & 6.87 & 297 \\
\hline Afghanistan & & & & & 0.1 & 0.1 & 0.00 & 1 \\
\hline Bangladesh & & & 2 & 18 & 25 & 45 & 0.91 & 66 \\
\hline Bhutan & & & & & 1 & 1 & 0.02 & 1 \\
\hline Maldives & & & & 7 & 1 & 8 & 0.17 & 5 \\
\hline Nepal & & 4 & 5 & 55 & 25 & 89 & 1.79 & 91 \\
\hline Pakistan & & & & & 3 & 3 & 0.05 & 1 \\
\hline Sri Lanka & 0.05 & 1 & 8 & 91 & 96 & 195 & 3.93 & 153 \\
\hline South-East Asia & 9 & 40 & 38 & 285 & 2002 & 2374 & 47.79 & 563 \\
\hline Cambodia & & & & & 15 & 15 & 0.29 & * \\
\hline Indonesia & & 13 & 2 & 26 & 138 & 179 & 3.60 & 52 \\
\hline Malaysia & 8 & 9 & 7 & 60 & 32 & 116 & 2.34 & 102 \\
\hline Myanmar & & & & 3 & 63 & 66 & 1.34 & 3 \\
\hline Philippines & & 2 & 0.2 & & 10 & 12 & 0.23 & 11 \\
\hline Singapore & & 3 & 24 & 158 & 1557 & 1741 & 35.05 & 377 \\
\hline Thailand & 0.3 & 14 & 6 & 35 & 111 & 166 & 3.35 & 59 \\
\hline Vietnam & & & & 2 & 76 & 79 & 1.58 & 11 \\
\hline Oceania & & 0.2 & 0.1 & 0.1 & 2 & 3 & 0.06 & 2 \\
\hline Fiji & & 0.2 & & & & 0.2 & 0.00 & 1 \\
\hline Solomon Islands & & & 0.05 & & & 0.05 & 0.00 & 1 \\
\hline Tonga & & & 0.02 & & & 0.02 & 0.00 & 1 \\
\hline Vanuatu & & & & 0.1 & 2 & 3 & 0.05 & 2 \\
\hline
\end{tabular}

* There are two OFDI approvals but names of investing Indian companies are not available. Note and source: Same as Table 1. 
TABLE A6. Sectoral Composition of Indian FDI Flows into Asia and Oceania, 1961-2007

\begin{tabular}{|c|c|c|c|c|c|c|c|c|c|}
\hline \multirow{3}{*}{ Industry } & \multicolumn{7}{|c|}{ FDI flows in $\$$ million } & \multirow{3}{*}{$\begin{array}{c}\text { No. } \\
\text { of } \\
\text { firms }\end{array}$} & \multirow{3}{*}{$\begin{array}{c}\text { No. } \\
\text { of } \\
\text { countries }\end{array}$} \\
\hline & \multirow{2}{*}{$\begin{array}{c}1961- \\
1969\end{array}$} & \multirow{2}{*}{\begin{tabular}{|c|}
$1970-$ \\
1979 \\
\end{tabular}} & \multirow{2}{*}{$\begin{array}{c}1980- \\
1989\end{array}$} & \multirow{2}{*}{$\begin{array}{c}1990- \\
1999\end{array}$} & \multirow{2}{*}{$\begin{array}{l}2000- \\
2007\end{array}$} & \multicolumn{2}{|c|}{ All years } & & \\
\hline & & & & & & Value & Per cent & & \\
\hline Primary & & 4 & 1 & 190 & 319 & 513 & 10.32 & 71 & 18 \\
\hline Agriculture \& allied products & & & 1 & 9 & 4 & 13 & 0.26 & 34 & 9 \\
\hline Ores \& minerals & & 4 & & 2 & 2 & 8 & 0.15 & 12 & 5 \\
\hline Gas, petroleum and related products & & & & 180 & 313 & 492 & 9.91 & 25 & 17 \\
\hline Manufacturing & 9 & 37 & 20 & 944 & 1848 & 2857 & 57.51 & 749 & 33 \\
\hline Food, beverages and tobacco & & 3 & 3 & 71 & 38 & 116 & 2.33 & 80 & 13 \\
\hline Textiles and wearing apparel & 0.3 & 14 & 1 & 24 & 52 & 91 & 1.84 & 83 & 15 \\
\hline Wood \& wood products & & & & 0.1 & 1 & 1 & 0.02 & 3 & 4 \\
\hline Paper and paper products & & 8 & & 23 & 7 & 39 & 0.78 & 13 & 8 \\
\hline Printing and publication & & & & 0.4 & 8 & 9 & 0.18 & 10 & 5 \\
\hline Gems and jewellery & & & 0.004 & 2 & 92 & 94 & 1.89 & 45 & 8 \\
\hline Leather and related products & & & & 11 & 16 & 27 & 0.54 & 20 & 8 \\
\hline Rubber and plastic products & & 0.3 & 1 & 20 & 38 & 59 & 1.19 & 61 & 12 \\
\hline Non-metallic mineral products & 6 & & & 67 & 26 & 98 & 1.98 & 44 & 11 \\
\hline Basic metals and fabricated metal product & & 4 & 5 & 55 & 338 & 402 & 8.09 & 79 & 16 \\
\hline Machinery and equipment & 0.05 & 0.2 & 2 & 17 & 51 & 70 & 1.42 & 68 & 17 \\
\hline Electrical machinery and equipment & & & 1 & 28 & 159 & 188 & 3.78 & 74 & 16 \\
\hline Transport equipment & & 4 & 0.3 & 3 & 439 & 447 & 8.99 & 34 & 11 \\
\hline Computer, electronic, medical, precision & & 0.3 & & 280 & 174 & 455 & 9.15 & 54 & 15 \\
\hline Chemicals & & 2 & 3 & 290 & 251 & 547 & 11.01 & 112 & 23 \\
\hline Pharmaceuticals & & & 3 & 43 & 150 & 196 & 3.95 & 58 & 16 \\
\hline Other manufacturing & 3 & 1 & 1 & 9 & 6 & 19 & 0.39 & 22 & 12 \\
\hline Services & & 5 & 40 & 301 & 1239 & 1586 & 31.92 & 520 & 24 \\
\hline Construction and engineering services & & 2 & 1 & 40 & 164 & 207 & 4.16 & 66 & 19 \\
\hline Trading & & & 5 & 14 & 3 & 21 & 0.43 & 29 & 9 \\
\hline Advertising and market research & & & & 2 & 8 & 10 & 0.21 & 20 & 8 \\
\hline Consultancy and business advisory service & & 0.002 & & 2 & 7 & 8 & 0.16 & 44 & 12 \\
\hline Event Management & & & & & 1 & 1 & 0.02 & 4 & 3 \\
\hline Film, entertainment and broadcasting & & & & 1 & 263 & 263 & 5.30 & 15 & 5 \\
\hline Hospitality and tourism & & 1 & 8 & 158 & 19 & 185 & 3.73 & 35 & 12 \\
\hline Hospital and health services & & & & 6 & 5 & 11 & 0.21 & 6 & 4 \\
\hline Financial and insurance services & & 2 & 26 & 11 & 26 & 65 & 1.31 & 46 & 13 \\
\hline Telecommunication services & & & & 10 & 285 & 296 & 5.95 & 8 & 7 \\
\hline Transportation services & & & 1 & 16 & 45 & 63 & 1.26 & 52 & 12 \\
\hline Software development, packages and ITES & & & 0.01 & 39 & 411 & 451 & 9.07 & 216 & 16 \\
\hline Other services & & & 0.1 & 3 & 2 & 5 & 0.10 & 18 & 9 \\
\hline Others & & & 0.2 & 10 & 2 & 12 & 0.24 & 25 & 11 \\
\hline Total & 9 & 46 & 61 & 1445 & 3407 & 4968 & 100 & 1298 & 35 \\
\hline
\end{tabular}

Note and source: Same as Table 1. 
44 ECONOMÍA: TEORÍA Y PRÁCTICA • Nueva Época, número 29, julio-diciembre 2008

TABLE A7. Indian FDI Flows into South-East Europe and CIS, by Destination,

1970-2007

\begin{tabular}{|c|c|c|c|c|c|c|c|}
\hline \multirow{3}{*}{ Region/Country } & \multicolumn{6}{|c|}{ FDI flows in $\$$ million } & \multirow{3}{*}{$\begin{array}{c}\text { Number of } \\
\text { investing } \\
\text { firms }\end{array}$} \\
\hline & \multirow{2}{*}{ 1970-1979 } & \multirow{2}{*}{$1980-1989$} & \multirow{2}{*}{$1990-1999$} & \multirow{2}{*}{$2000-2007$} & \multicolumn{2}{|c|}{ All years } & \\
\hline & & & & & Value & Per cent & \\
\hline South-East Europe \& the CIS & 2 & 29 & 81 & 1281 & 1394 & 100 & 112 \\
\hline South-East Europe & 2 & & 0.2 & 11 & 14 & 0.99 & 8 \\
\hline Bosnia \& Herzegovina & 2 & & & & 2 & 0.17 & 1 \\
\hline Bulgaria & & & 0.2 & 0.3 & 1 & 0.04 & 3 \\
\hline Romania & & & & 11 & 11 & 0.78 & 4 \\
\hline CIS & & 29 & 81 & 1270 & 1380 & 99.01 & 105 \\
\hline Azerbaijan & & & 1 & 2 & 3 & 0.20 & 4 \\
\hline Belarus & & & 0.2 & & 0.2 & 0.01 & 1 \\
\hline Georgia & & & 1 & 8 & 9 & 0.63 & 4 \\
\hline Kazakhstan & & 29 & 10 & 135 & 174 & 12.47 & 11 \\
\hline Kyrgyzstan & & & 8 & 5 & 13 & 0.92 & 7 \\
\hline Maldova & & & & 7 & 7 & 0.47 & 1 \\
\hline Russia & & 1 & 34 & 1093 & 1128 & 80.89 & 60 \\
\hline Tajikistan & & & 1 & 4 & 5 & 0.37 & 4 \\
\hline Turkmenistan & & & 2 & & 2 & 0.13 & 3 \\
\hline Ukraine & & & 1 & 4 & 5 & 0.37 & 8 \\
\hline Uzbekistan & & & 24 & 12 & 35 & 2.53 & 18 \\
\hline
\end{tabular}

Note and source: Same as Table 1. 
TABLE A8. Sectoral Composition of Indian FDI Flows into South-East Europe and CIS, 1970-2007

\begin{tabular}{|c|c|c|c|c|c|c|c|c|}
\hline \multirow{3}{*}{ Industry } & \multicolumn{6}{|c|}{ FDI flows in $\$$ million } & \multirow{3}{*}{$\begin{array}{c}\text { No. } \\
\text { of } \\
\text { firms }\end{array}$} & \multirow{3}{*}{$\begin{array}{c}\text { No. } \\
\text { of } \\
\text { countries }\end{array}$} \\
\hline & \multirow{2}{*}{$\begin{array}{l}1970- \\
1979\end{array}$} & \multirow{2}{*}{$\begin{array}{c}1980- \\
1989\end{array}$} & \multirow{2}{*}{$\begin{array}{c}1990- \\
1999\end{array}$} & \multirow{2}{*}{$2000-2007$} & \multicolumn{2}{|c|}{ All years } & & \\
\hline & & & & & Value & Per cent & & \\
\hline Primary & & & 3 & 1071 & 1074 & 77.01 & 5 & 4 \\
\hline Agriculture \& allied products & & & 0.4 & 0.3 & 1 & 0.05 & 2 & 3 \\
\hline Gas, petroleum and related products & & & 3 & 1070 & 1073 & 76.96 & 3 & 2 \\
\hline Manufacturing & 2 & 29 & 62 & 72 & 164 & 11.80 & 72 & 13 \\
\hline Food, beverages and tobacco & & & 10 & 5 & 14 & 1.03 & 12 & 5 \\
\hline Textiles and wearing apparel & & & 8 & 0.1 & 9 & 0.61 & 6 & 3 \\
\hline Paper and paper products & & & 0.1 & & 0.1 & 0.01 & 1 & 1 \\
\hline Printing and publication & & & 0.4 & & 0.4 & 0.03 & 1 & 1 \\
\hline Gems and jewellery & & & & 0.0001 & 0.0001 & 0.00 & & \\
\hline Leather and related products & & & 7 & 0.3 & 7 & 0.50 & 8 & 4 \\
\hline Rubber and plastic products & & & 2 & 0.1 & 2 & 0.15 & 5 & 5 \\
\hline Non-metallic mineral products & & & & 0.01 & 0.01 & 0.00 & 1 & 1 \\
\hline Basic metals and fabricated metal product & 2 & & 2 & 0.001 & 5 & 0.34 & 3 & 3 \\
\hline Machinery and equipment & & & 3 & 1 & 4 & 0.29 & 6 & 2 \\
\hline Electrical machinery and equipment & & & & 7 & 7 & 0.52 & 1 & 1 \\
\hline Computer, electronic, medical, precision & & & 1 & & 1 & 0.08 & 4 & 2 \\
\hline Chemicals & & 29 & 1 & 1 & 30 & 2.16 & 4 & 4 \\
\hline Pharmaceuticals & & & 22 & 58 & 80 & 5.77 & 21 & 9 \\
\hline Other manufacturing & & & 4 & & 4 & 0.30 & 2 & 2 \\
\hline Services & & 1 & 16 & 138 & 155 & 11.13 & 37 & 10 \\
\hline Construction and engineering services & & & 0.2 & 137 & 137 & 9.86 & 7 & 4 \\
\hline Trading & & 1 & 6 & 0.1 & 7 & 0.48 & 11 & 2 \\
\hline Consultancy and business advisory service & & & 0.2 & & 0.2 & 0.02 & 1 & 1 \\
\hline Film, entertainment and broadcasting & & & & 0.1 & 0.1 & 0.00 & 1 & 1 \\
\hline Hospitality and tourism & & 0.2 & 9 & 1 & 10 & 0.73 & 13 & 8 \\
\hline Financial and insurance services & & & 0.1 & & 0.1 & 0.01 & 2 & 2 \\
\hline Software development, packages and ITES & & & 0.2 & 0.4 & 1 & 0.04 & 3 & 2 \\
\hline Others & & & 1 & 0.03 & 1 & 0.06 & 5 & 2 \\
\hline Total & 2 & 29 & 81 & 1281 & 1394 & 100 & 112 & 25 \\
\hline
\end{tabular}

Note and source: Same as Table 1. 
46 ECONOMÍA: TEORÍA Y PRÁCTICA • Nueva Época, número 29, julio-diciembre 2008

TABLE A9. Ownership Choice of Indian Firms Investing in Developing Region, 1961-2007

\begin{tabular}{|c|c|c|c|c|c|c|}
\hline \multirow{3}{*}{ Ownership Mode } & \multicolumn{6}{|c|}{ Number of OFDI Approvals } \\
\hline & \multirow{2}{*}{ Africa } & \multirow{2}{*}{$\begin{array}{l}\text { Latin America } \\
\text { and Caribbean }\end{array}$} & \multirow{2}{*}{$\begin{array}{l}\text { Asia and } \\
\text { Oceania }\end{array}$} & \multirow{2}{*}{$\begin{array}{c}\text { Southeast } \\
\text { Europe and } \mathrm{CIS}\end{array}$} & \multicolumn{2}{|c|}{ Total developing region } \\
\hline & & & & & Number & Percentage share \\
\hline \multicolumn{7}{|c|}{ 1961-1969 } \\
\hline JV & 3 & & 4 & & 7 & 100 \\
\hline wos & & & & & & 0 \\
\hline Total & 3 & & 4 & & 7 & 100 \\
\hline \multicolumn{7}{|c|}{ 1970-1979 } \\
\hline $\mathrm{JV}$ & 12 & & 45 & 1 & 58 & 95.1 \\
\hline wos & & & 3 & & 3 & 4.9 \\
\hline Total & 12 & & 48 & 1 & 61 & 100 \\
\hline \multicolumn{7}{|c|}{ 1980-1989 } \\
\hline $\mathrm{JV}$ & 14 & 2 & 60 & 3 & 79 & 87.8 \\
\hline wos & 2 & & 9 & & 11 & 12.2 \\
\hline Total & 16 & 2 & 69 & 3 & 90 & 100 \\
\hline \multicolumn{7}{|c|}{ 1990-1999 } \\
\hline$J V$ & 73 & 13 & 409 & 86 & 581 & 58.9 \\
\hline wos & 122 & 13 & 243 & 27 & 405 & 41.1 \\
\hline Total & 195 & 26 & 652 & 113 & 986 & 100 \\
\hline \multicolumn{7}{|c|}{$2000-2007$} \\
\hline JV & 153 & 37 & 580 & 39 & 809 & 27.7 \\
\hline wos & 441 & 145 & 1455 & 69 & 2110 & 72.3 \\
\hline Total & 594 & 182 & 2035 & 108 & 2919 & 100 \\
\hline \multicolumn{7}{|c|}{ All Years } \\
\hline $\mathrm{JV}$ & 255 & 52 & 1098 & 129 & 1534 & 37.8 \\
\hline wos & 565 & 158 & 1710 & 96 & 2529 & 62.2 \\
\hline Total & 820 & 210 & 2808 & 225 & 4063 & 100 \\
\hline $\begin{array}{c}\text { Percentage share } \\
\text { of wos }\end{array}$ & 69 & 75 & 61 & 43 & 62 & 62 \\
\hline
\end{tabular}

Note and source: Same as Table 1. 
TABLE A10. Regional and Sectoral Pattern of Indian Firms' Acquisition in Developing Region, 2000-2008

\begin{tabular}{|c|c|c|c|c|c|}
\hline \multicolumn{6}{|c|}{ Acquisitions in US\$ million/number } \\
\hline Region & Value & Number & Sector & Value & Number \\
\hline Africa & $\begin{array}{l}3439 \\
(27.8)\end{array}$ & $\begin{array}{c}37 \\
(22.3)\end{array}$ & Primary & $\begin{array}{l}7402 \\
(59.9)\end{array}$ & $\begin{array}{c}32 \\
(19.3)\end{array}$ \\
\hline North Africa & $\begin{array}{l}1190 \\
(9.6)\end{array}$ & $\begin{array}{c}10 \\
(6.0)\end{array}$ & Mining & $\begin{array}{c}1527 \\
(12.4)\end{array}$ & $\begin{array}{c}8 \\
(4.8)\end{array}$ \\
\hline West Africa & $\begin{array}{c}3 \\
(0.0)\end{array}$ & $\begin{array}{c}3 \\
(1.8)\end{array}$ & Oil and gas & $\begin{array}{l}5875 \\
(47.6)\end{array}$ & $\begin{array}{c}24 \\
(14.5)\end{array}$ \\
\hline East Africa & $\begin{array}{c}1304 \\
(10.6)\end{array}$ & $\begin{array}{c}10 \\
(6.0)\end{array}$ & Manufacturing & $\begin{array}{l}3530 \\
(28.6)\end{array}$ & $\begin{array}{c}78 \\
(47.0)\end{array}$ \\
\hline Southern Africa & $\begin{array}{c}942 \\
(7.6)\end{array}$ & $\begin{array}{c}14 \\
(8.4)\end{array}$ & Food and beverages & $\begin{array}{c}0.5 \\
(0.0)\end{array}$ & $\begin{array}{c}3 \\
(1.8)\end{array}$ \\
\hline Latin America and the Caribbean & $\begin{array}{c}509 \\
(4.1)\end{array}$ & $\begin{array}{c}19 \\
(11.4)\end{array}$ & Textiles and wearing apparel & $\begin{array}{c}93 \\
(0.8)\end{array}$ & $\begin{array}{c}6 \\
(3.6)\end{array}$ \\
\hline South America & $\begin{array}{l}450 \\
(3.6)\end{array}$ & $\begin{array}{c}15 \\
(9.0)\end{array}$ & Plastic and products & $\begin{array}{c}16 \\
(0.1)\end{array}$ & $\begin{array}{c}3 \\
(1.8)\end{array}$ \\
\hline Central America & $\begin{array}{c}59 \\
(0.5)\end{array}$ & $\begin{array}{c}2 \\
(1.2)\end{array}$ & Metal and fabricated metal products & $\begin{array}{l}1163 \\
(9.4)\end{array}$ & $\begin{array}{c}10 \\
(6.0)\end{array}$ \\
\hline Caribbean and other America & $\begin{array}{c}0.3 \\
(0.0)\end{array}$ & $\begin{array}{c}2 \\
(1.2)\end{array}$ & Electrical machinery and equipment & $\begin{array}{c}109 \\
(0.9)\end{array}$ & $\begin{array}{c}3 \\
(1.8)\end{array}$ \\
\hline Asia and Oceania & $\begin{array}{l}5901 \\
(47.8)\end{array}$ & $\begin{array}{c}96 \\
(57.8)\end{array}$ & Telecommunication equipment & $\begin{array}{l}752 \\
(6.1)\end{array}$ & $\begin{array}{c}1 \\
(0.6)\end{array}$ \\
\hline West Asia & $\begin{array}{l}1119 \\
(9.1)\end{array}$ & $\begin{array}{c}10 \\
(6.0)\end{array}$ & Transport equipment & $\begin{array}{c}193 \\
(1.6)\end{array}$ & $\begin{array}{c}9 \\
(5.4)\end{array}$ \\
\hline East Asia & $\begin{array}{l}1040 \\
(8.4)\end{array}$ & $\begin{array}{c}22 \\
(13.3)\end{array}$ & Chemicals & $\begin{array}{c}704 \\
(5.7)\end{array}$ & $\begin{array}{c}22 \\
(13.3)\end{array}$ \\
\hline South Asia & $\begin{array}{c}2 \\
(0.01)\end{array}$ & $\begin{array}{c}3 \\
(1.8)\end{array}$ & Pharmaceuticals & $\begin{array}{l}500 \\
(4.0)\end{array}$ & $\begin{array}{c}19 \\
(11.4)\end{array}$ \\
\hline South-East Asia & $\begin{array}{l}3739 \\
(30.3)\end{array}$ & $\begin{array}{c}60 \\
(36.1)\end{array}$ & Services & $\begin{array}{c}781 \\
(6.3)\end{array}$ & $\begin{array}{c}51 \\
(30.7)\end{array}$ \\
\hline Oceania & $\begin{array}{c}1 \\
(0.0)\end{array}$ & $\begin{array}{c}1 \\
(0.6)\end{array}$ & Banking and financial services & $\begin{array}{c}53 \\
(0.4)\end{array}$ & $\begin{array}{c}6 \\
(3.6)\end{array}$ \\
\hline South-East Europe and the CIS & $\begin{array}{c}2501 \\
(20.3)\end{array}$ & $\begin{array}{c}14 \\
(8.4)\end{array}$ & Hospitality and tourism & $\begin{array}{l}254 \\
(2.1)\end{array}$ & $\begin{array}{c}3 \\
(1.8)\end{array}$ \\
\hline South-East Europe & $\begin{array}{c}679 \\
(5.5)\end{array}$ & $\begin{array}{c}9 \\
(5.4)\end{array}$ & Telecommunication services & $\begin{array}{c}60 \\
(0.5)\end{array}$ & $\begin{array}{c}5 \\
(3.0)\end{array}$ \\
\hline \multirow[t]{2}{*}{ CIS } & $\begin{array}{c}1822 \\
(14.8)\end{array}$ & $\begin{array}{c}5 \\
(3.0)\end{array}$ & Media and entertainment & $\begin{array}{c}55 \\
(0.4)\end{array}$ & $\begin{array}{c}6 \\
(3.6)\end{array}$ \\
\hline & & & IT and ITES & $\begin{array}{c}358 \\
(2.9)\end{array}$ & $\begin{array}{c}29 \\
(17.5)\end{array}$ \\
\hline Developing region & $\begin{array}{c}12350 \\
(100)\end{array}$ & $\begin{array}{c}166 \\
(100)\end{array}$ & All sectors & $\begin{array}{c}12350 \\
(100)\end{array}$ & $\begin{array}{c}166 \\
(100)\end{array}$ \\
\hline
\end{tabular}

Note and source: Same as Table 3. 


\section{REFERENCE}

Agrawal, R. G. (1984), Joint Ventures Abroad: Indian Experience, Publication Division, Ministry of Information and Broadcasting, Government of India, New Delhi.

Aykut, D. and A. Goldstein (2007), 'Developing Country Multinationals: South-South Investment Comes of Age', in United Nations (ed.), Industrial Development for the 21 $1^{\text {st }}$ Century: Sustainable Development Perspectives, New York, pp. 85-116. and D. Rath (2004), 'South-South FDI Flows: How Big Are They?', Transnational Corporations, 13, pp. 149-176.

Bhattat, J. and D. Aykut (2005), ‘Southern Multinationals: A Growing Phenomenon', IFCFinancial Times Conference on Southern Multinationals, Mumbai, India.

Desai, A.V. (1984) 'India's technological capability: An analysis of its achievements and limits', Research Policy, 13, pp. 303-310.

FICCI (1982), Workshop on Indian Joint Ventures Abroad and Project Exports, Federation of Indian Chambers of Commerce \& Industry, New Delhi.

Goldstein, A. (2007), Multinational Companies from Emerging Economies: Composition, Conceptualization and Direction in the Global Economy, New York: Palgrave Macmillan.

Indian Institute of Foreign Trade/IIFT (1977), India's Joint Ventures Abroad, New Delhi.

Lall, R. B. (1986), Multinationals from the Third World: Indian Firms Investing Abroad, Delhi: Oxford University Press.

Lall, S. (1983), (ed.) The New Multinationals: The Spread of Third World Enterprises, John Wiley \& Sons New York.

Pradhan, J. P. (2003), 'Rise of Service Sector Outward Foreign Direct Investment from Indian Economy: Trends, Patterns, and Determinants', RIS Discussion Paper (RIS-DP) \#63/2003.

(2006), 'Quality of Foreign Direct Investment, Knowledge Spillovers and Host Country Productivity: A Framework of Analysis', ISID Working Paper, No. 2006/11, New Delhi.

- (2008a), Indian Multinationals in the World Economy: Implications for Development, Bookwell Publisher, New Delhi.

_ (2008b), 'The Evolution of Indian Outward Foreign Direct Investment: Changing Trends and Patterns', International Journal of Technology and Globalisation, 4, pp.70-86.

and M. K. Sahu (2007), 'Outward Foreign Direct Investment by Small and Medium-Sized Enterprises from India’, in UNCTAD (2007) Global Players from 
Emerging Markets: Strengthening Enterprise Competitiveness through Outward Investment, United Nations, New York and Geneva, pp. 67-80.

Pradhan, J. P. and Neelam Singh (2008) 'Outward FDI and Knowledge Flows: A Study of the Indian Automotive Sector', ISID Working Paper, No. 2008/2010, New Delhi. and V. Abraham (2005), 'Overseas Mergers and Acquisitions by Indian Enterprises: Patterns and Motivations', Indian Journal of Economics, Vol. LXXXV, pp. 365-386.

Ranganathan, K. V. K. (1990), Export Promotion and Indian Joint Ventures, Unpublished, $\mathrm{Ph}$. D. thesis, Kurukshetra University, India. 